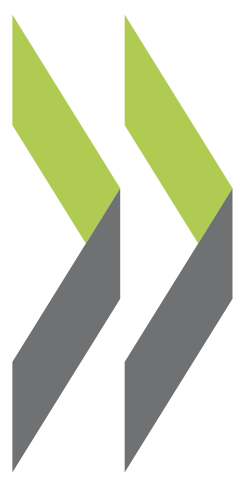

OECD Economics Department Working Papers No. 1423

\author{
Towards more inclusive \\ growth in Colombia
}

Christine de la Maisonneuve 
Organisation de Coopération et de Développement Économiques

Organisation for Economic Co-operation and Development

16-Oct-2017

ECONOMICS DEPARTMENT

English - Or. English

\section{TOWARDS MORE INCLUSIVE GROWTH IN COLOMBIA}

ECONOMICS DEPARTMENT WORKING PAPERS No. 1423

By Christine de la Maisonneuve

OECD Working Papers should not be reported as representing the official views of the OECD or of its member countries. The opinions expressed and arguments employed are those of the author(s).

Authorised for publication by Alvaro Pereira, Director, Country Studies Branch, Economics Department.

All Economics Department Working Papers are available at www.oecd.org/eco/workingpapers. 
OECD Working Papers should not be reported as representing the official views of the OECD or of its member countries. The opinions expressed and arguments employed are those of the author(s).

Working Papers describe preliminary results or research in progress by the author(s) and are published to stimulate discussion on a broad range of issues on which the OECD works.

Comments on Working Papers are welcomed, and may be sent to OECD Economics Department, 2 Rue André-Pascal, 75775 Paris Cedex 16, France, or by e-mail to eco.contact@ oecd.org.

All Economics Department Working Papers are available at www.oecd.org/eco/workingpapers.

This document and any map included herein are without prejudice to the status of or sovereignty over any territory, to the delimitation of international frontiers and boundaries and to the name of any territory, city or area.

The statistical data for Israel are supplied by and under the responsibility of the relevant Israeli authorities. The use of such data by the OECD is without prejudice to the status of the Golan Heights, East Jerusalem and Israeli settlements in the West Bank under the terms of international law.

(C) OECD (2017)

You can copy, download or print OECD content for your own use, and you can include excerpts from OECD publications, databases and multimedia products in your own documents, presentations, blogs, websites and teaching materials, provided that suitable acknowledgment of OECD as source and copyright owner is given. All requests for commercial use and translation rights should be submitted to rights@oecd.org 


\section{ABSTRACT/RÉSUMÉ}

\section{Towards more inclusive growth in Colombia}

Growth has become more inclusive in recent years in Colombia. Strong growth and targeted social policies have reduced absolute poverty. Conditional cash transfers and education policies have increased attendance in schools. Universal health care is improving wellbeing of many Colombians. Reductions in non-wage labour costs have increased formal employment and access to social benefits. However, income inequality remains high with large disparities across regions. The causes are many. High informality keeps many workers in low quality jobs without social benefits or access to finance. Inequality is a gender issue as labour force participation rates and wages are lower for women than for men. Inequalities also reflect low social mobility as opportunities for education and jobs are influenced by socio-economic backgrounds. More targeted programmes are necessary to increase education enrolment rates of disadvantaged children in less developed regions. Further reductions in non-wage labour costs can raise formal employment. Better access to labour market programmes, early childhood education and elderly and disability care can boost female labour market participation. More resources are needed for targeted social programmes to achieve stronger outcomes. A comprehensive pension system reform is needed to extend coverage and alleviate old-age poverty.

This Working Paper relates to the 2017 OECD Economic Survey of Colombia (www.oecd.org/eco/surveys/economic-survey-colombia.htm)

JEL codes: E24, E26, H20, H50, I0, J0

Keywords: Inclusive growth, Labour market, Informality, Inequality, Social protection, Health, Education, Pensions, Regional Development

$* * * * *$

\section{Vers une croissance plus inclusive en Colombie}

La croissance est devenue plus inclusive en Colombie ces dernières années. Une croissance forte et des politiques sociales bien ciblées ont permis de réduire la pauvreté absolue. Les transferts conditionnels en espèces et les politiques d'éducation ont permis une augmentation de la scolarisation. La couverture universelle pour les soins de santé améliore le bien-être de nombreux colombiens. La baisse des coûts du travail nonsalariaux a permis une augmentation de l'emploi formel et de l'accès aux prestations sociales. Les inégalités de revenu restent néanmoins élevées avec des disparités régionales importantes. Les causes sont nombreuses. Le niveau élevé du travail informel se traduit par un nombre important de travailleurs occupant des emplois de faible qualité et ne bénéficiant ni de prestations sociales ni d'accès au financement. Les inégalités concernent les hommes et les femmes différemment, les taux de participation et les salaires des femmes étant inférieurs à ceux des hommes. Les inégalités reflètent aussi une faible mobilité sociale, les opportunités d'éducation et d'emploi étant influencées par le milieu socioéconomique. Des programmes mieux ciblés sont nécessaires pour augmenter les taux de scolarisation des enfants défavorisés dans les régions les moins développées. Des réductions supplémentaires des coûts du travail non-salariaux aideront à promouvoir l'emploi formel. Un meilleur accès aux programmes du marché du travail, à l'éducation de la petite enfance et aux soins des personnes âgées et handicapées pourrait promouvoir la participation des femmes sur le marché du travail. Des ressources supplémentaires sont nécessaires pour que les programmes sociaux ciblés produisent de meilleurs résultats. Une réforme globale du système des retraites est nécessaire pour augmenter la couverture et soulager la pauvreté des personnes âgées.

Ce Document de travail se rapporte à l'Etude économique de l'OCDE de la Colombie 2017 (www.oecd.org/fr/eco/etudes/etude-economique-colombie.htm).

Classification JEL : E24, E26, H20, H50, I0, J0

Mots-clés : Croissance inclusive, Marché du travail, Informalité, Inégalités, Protection sociale, Santé, Éducation, Retraites, Développement régional 


\section{TABLE OF CONTENTS}

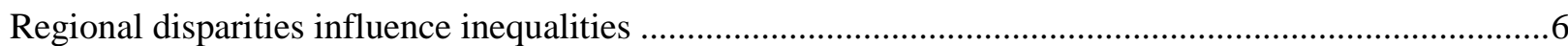

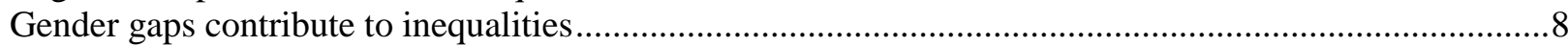

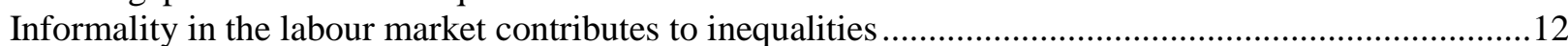

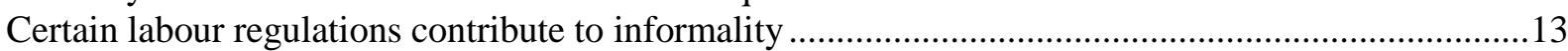

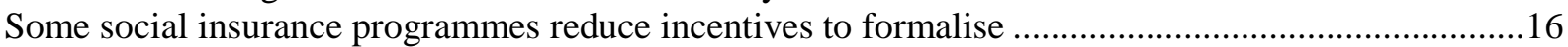

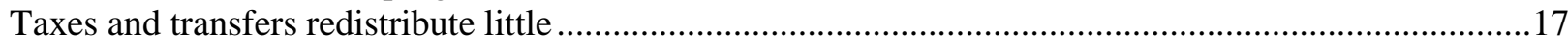

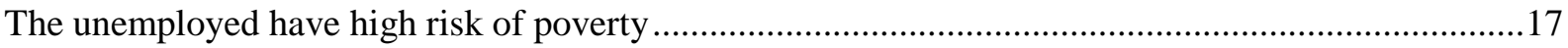

The social system has reduced inequality and poverty but could redistribute more ..............................18

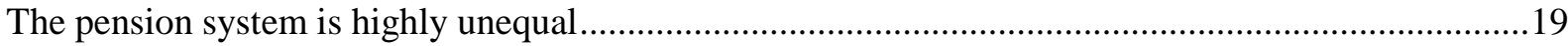

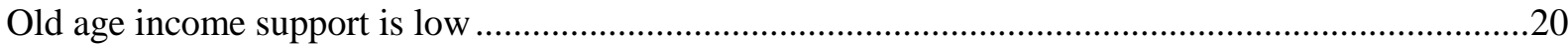

Health coverage is almost universal but access to quality services remains difficult for the poor and in

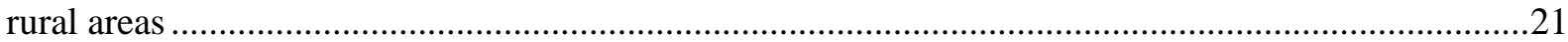

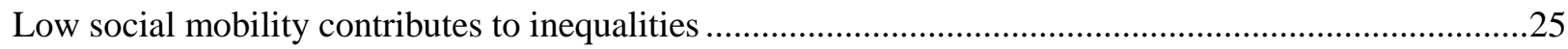

Education enrolment has increased significantly but disadvantaged groups remain behind....................25

Enhancing education opportunities can be tackled with targeted policies .........................................29

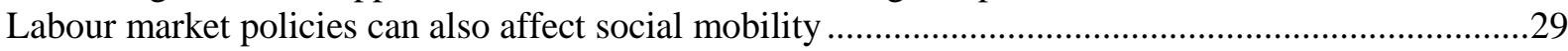

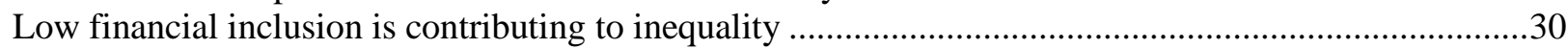

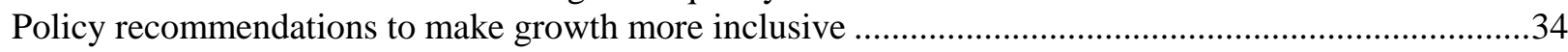

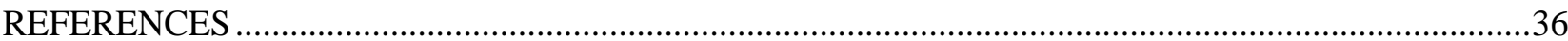

\section{Figures}

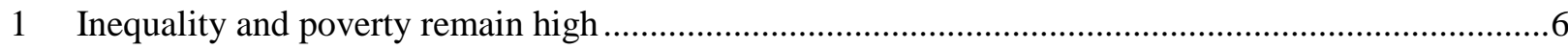

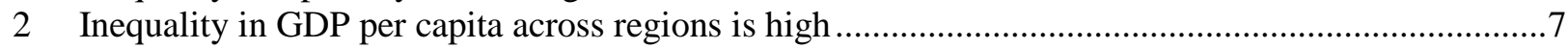

3 Gender gaps in labour force participation are declining but persist in Colombia...............................9

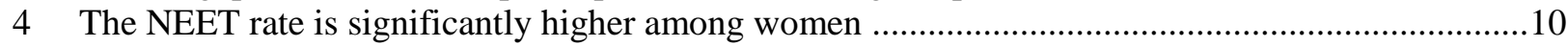

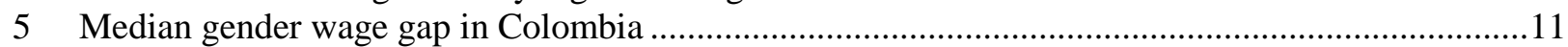

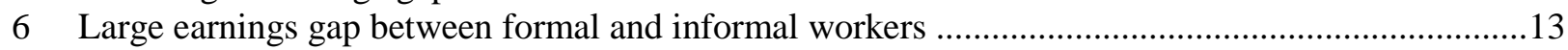

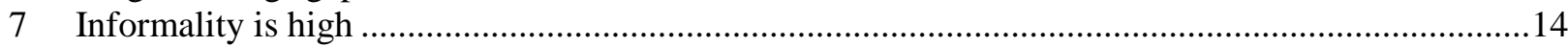

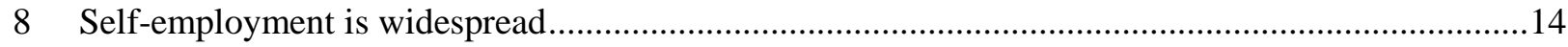

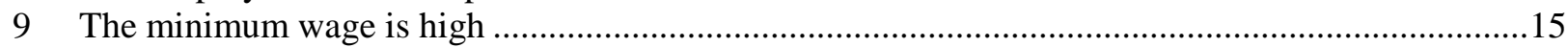

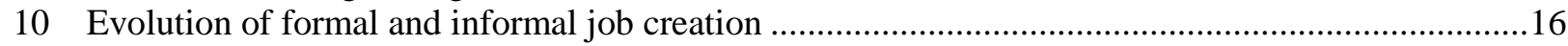

11 The tax and transfer system does little for redistribution................................................................17

12 Social spending in Colombia is much lower than the OECD average ..............................................18

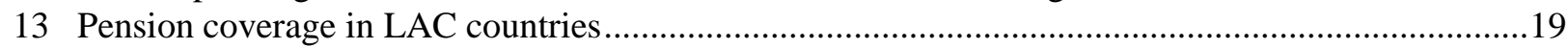

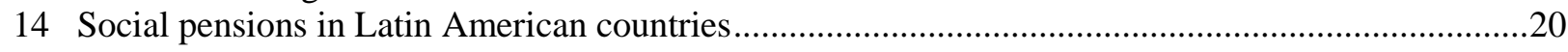

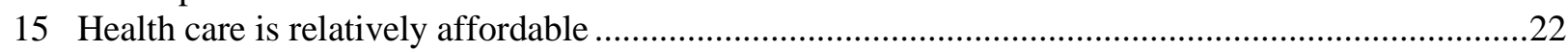

16 Health care resources and access to care remain worse in rural and remote areas ...........................24

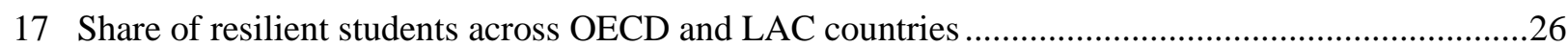

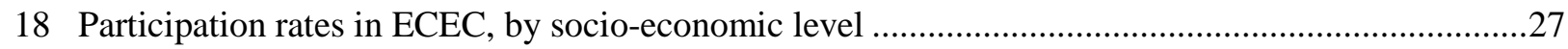

19 Share of adult population that has attained at least upper secondary education ...............................28

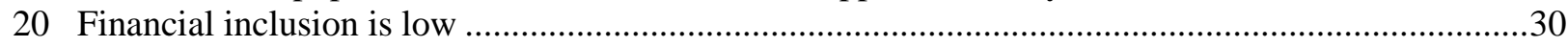

\section{Boxes}

Box 1. Financial inclusion: experience in selected countries ..........................................................32 


\title{
TOWARDS MORE INCLUSIVE GROWTH IN COLOMBIA
}

\author{
By Christine de la Maisonneuve ${ }^{1}$
}

The quality of life of Colombians has improved substantially over the last decade with rising incomes and declining poverty. Nevertheless, Colombia remains one of the most unequal countries in terms of income distribution compared to the OECD and much of Latin America. Too many people are still poor, and regional differences in income or access to public services are large (Figure 1). Income inequalities are also high within regions: Chocó, Cauca and Huila are most unequal, while Cundinamarca, Atlantico and Caqueta are most equal. Inequality is also a gender issue as female labour force participation is low, gender unemployment and wage gaps are high, and violence affects more women than men. Access to education and health is also uneven among regions and socioeconomic groups affecting wellbeing of Colombians, which in turn tends to exacerbate inequality of opportunity.

Making growth more inclusive thus remains an important challenge. Inequality can impede upward social mobility by limiting job opportunities and access to education for the poorest children (OECD, 2011). This has negative consequences for overall economic performance (OECD, 2011, Ferreira et al. 2014). Inequalities can also raise protectionist and anti-globalisation sentiment reducing trade and growth, and add to political challenges via social cohesion.

Inequality has many complex causes. High informality in the labour market keeps workers in marginal, insecure, low paying jobs without access to social benefits. As attainment in education is heavily influenced by social background, the large education premium exacerbates income disparities. Social policies also contribute: the redistributive impact of the current tax system is low and social welfare programmes do not reach a large share of the poor. The pension system covers only formal workers earning at least the minimum wage, which leaves many elderly without income. However, it is complemented by both Colombia Mayor and the BEPS programmes, which cover some of the low income elderly. Health coverage is universal, but the quality of health services varies between richer and poorer regions. Low social mobility, influenced by access to education, contributes to inequalities.

This chapter discusses causes of and progress in reducing inequality and poverty in Colombia, and makes policy recommendations for more inclusive growth. The first two sections cover regional disparities and the gender gap in the labour market. The second part discusses the main causes of inequality such as informality in the labour market, the social welfare system (health, social transfers, pensions and taxation), social mobility (education and labour and product market barriers) and financial inclusion.

\footnotetext{
${ }^{1}$ Christine de la Maisonneuve was economist on the Colombia desk at the time of writing this paper. This work benefited from important contributions by Eduardo Olaberria (who was working in the same department), Valerie Frey, (Directorate for Employment,Labour and Social Affairs) Apolline Jaoui and Thomas Manfredi (Directorate for Employment,Labour and Social Affairs). The paper has also benefitted from comments by members of the OECD Economic Development and Review Committee. The author would like to thank Bert Brys (Centre for Tax Policy and Administration), Veerle Miranda ((Directorate for Employment, Labour and Social Affairs), Anna Pons and Angelica Salvi del Pero (Directorate for Education and Skills), Álvaro Pereira, Robert Ford, Piritta Sorsa and Jon Pareliussen for valuable comments (Economics Department), all from OECD. Special thanks go to Pedro Herrera Gimenez for statistical research and Assa Fofana and Raquel Paramo for editorial assistance (also from the Economics Department).
} 
Figure 1. Inequality and poverty remain high

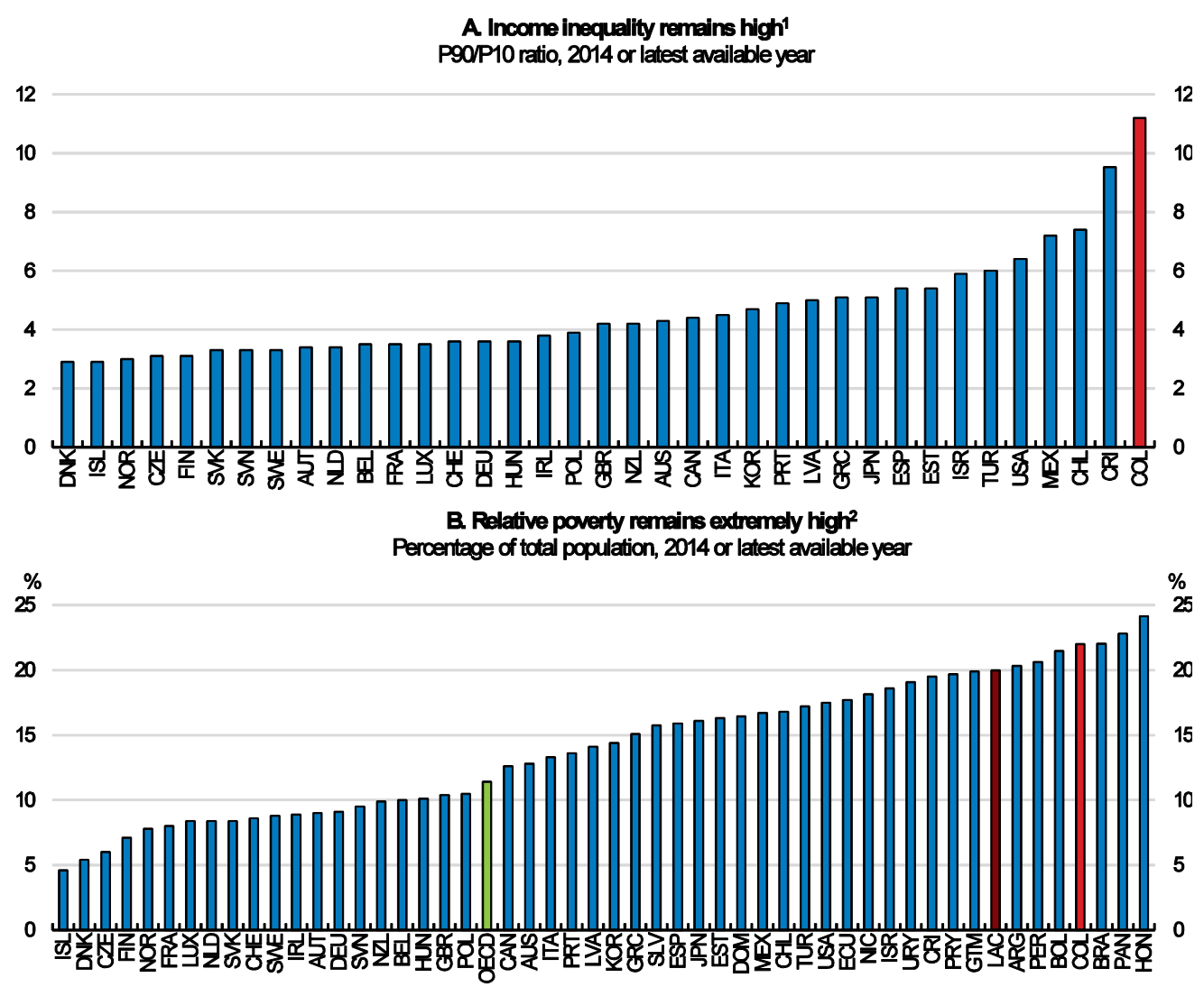

1. For Australia, Finland, Hungary, Israel, Korea, Mexico, Netherlands, United States, Colombia and Costa Rica, data refer to 2014. For Japan and New Zealand, data refer to 2012. The P90/P10 ratio is the ratio of income of the $10 \%$ of people with highest income to that of the poorest $10 \%$.

2. Relative poverty rates after taxes and transfers (threshold of $50 \%$ of the median income). LAC average does not include Chile and Mexico.

Source: OECD Social and Welfare Statistics and SEDLAC (CEDLAS and The World Bank) and; OECD (2016a), OECD Publishing, Paris.

\section{Regional disparities influence inequalities}

Regional inequality in GDP per capita, measured by the Gini index, is higher in Colombia than in the OECD and other large emerging market economies (Figure 2). For example, it would take the poorest department of Choco 200 years to converge to Bogota's income per capita levels at current growth rates (Galvis and Meisel, 2012). Resource-rich regions have grown faster than others and have higher GDP per capita, but they also have high poverty and inequality. This points to weak redistribution of incomes from oil and mining (OECD, 2014). Regional disparities and growth opportunities are also influenced by topography with high mountain ranges isolating regions in the absence of efficient infrastructure to connect them. Compared to other Latin American or OECD countries, the network of roads and railways is low relative to GDP per capita (Olaberria, 2017).

Agricultural departments have the highest poverty levels, and 50 years of armed conflict has driven 7 million people from rural areas to cities (desplazados), increasing urban poverty as many of them did not have skills required by the urban labour market. The government has launched an important program to 
support the conflict victims. In 2016, the total estimated budget allocation represented around $1.2 \%$ of GDP. The main components were education for $36 \%$, health $24 \%$, humanitarian attention $18 \%$, institutional strengthening $6 \%$, and others expenses $16 \%$. The same percentage is expected to be spent in 2017.

\section{Figure 2. Inequality in GDP per capita across regions is high}

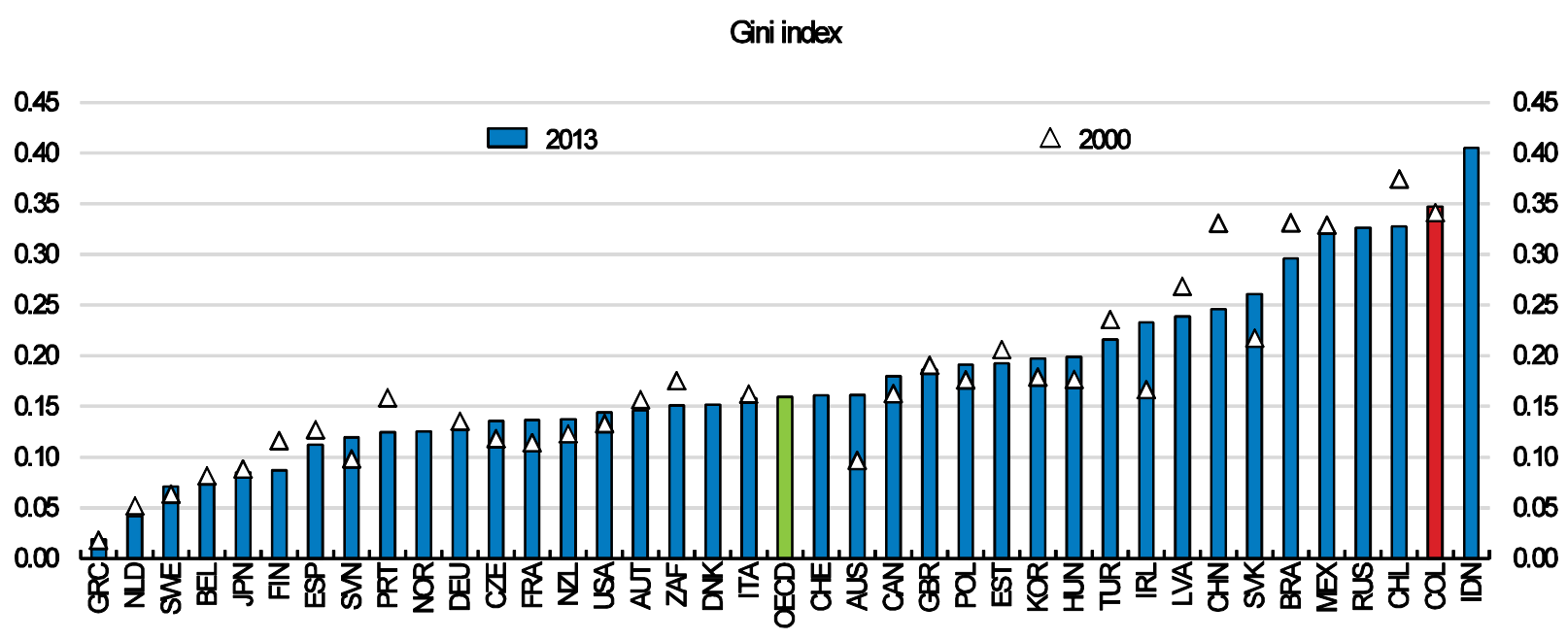

Note: The Gini index has a range from zero (when everybody has identical incomes) to one (when all income goes to only one person). Increasing values of the Gini coefficient thus indicate higher inequality in the distribution of income. For OECD, data refer to the average of 32 member countries.TL3 regions. Australia, Canada, Chile, Mexico, Turkey and the United States TL2 regions. Germany Non Official Grids regions. Brazil, China, Colombia, Indonesia, Russian Federation and South Africa TL2 regions. Regional GVA for Turkey. Regional GDP is not available for Iceland and Israel. For China, data for the Special Administrative Region of Hong Kong, the Special Administrative Region of Macau and Chinese Taipei are excluded. First available years: Japan and India 2001; Mexico 2003; China 2004. Last available year: Austria, Brazil, China, Colombia, Estonia, Finland, France, Germany, Hungary, Indonesia, Ireland, Italy, Japan, Latvia, Lithuania, Norway, Poland, Russian Federation, Spain, Sweden and Switzerland 2012.

Source: OECD (2016), OECD Regions at a Glance 2016, OECD Publishing, Paris.

Until recently, fiscal policies did little to reduce income disparities, as the revenue sharing system between the central and subnational governments (SGP) did not aim at fiscal equalisation. Many transfers were earmarked, and the better ability of higher-income departments and municipalities to raise tax revenue locally was not shared with the poorer regions.

The reform of the General System of Royalties (SGR) in 2011-12 has reduced these inequalities by sharing royalty revenues from the oil and mining sector more evenly across departments (Bonet and Urrego, 2014). This has important potential implications as royalties finance a large share of public investment. Since the reform, sub-national governments have invested royalty revenues in four main areas: improving road connectivity, research and development projects, improving the delivery of education in the regions and purifying water (OECD, 2014). The additional funds allocated point to a more inclusive approach to regional development (OECD, 2014), which should help reduce regional economic disparities over time. The allocation of the revenues is transparent and based on a formula that measures regional poverty rates and population. The aim is to concentrate additional investment in territories that suffer from poverty and poor access to basic public services. Most of these areas are rural and remote.

Agriculture and rural development have been part of the National Development Plans since the 1990s. Rural development policy has promoted equitable access to credit and land, as well as housing, basic sanitation, education and health (OECD, 2015a). However, these policies have only had limited effect in raising incomes and reducing inequality and challenges remain. 
Low incomes in agriculture-dominated regions are influenced by weak property rights. A weak rural property registry ("cadastre") and a complex legal framework have contributed to significant underinvestment and inefficiencies in land utilisation. The cadastre system should be upgraded and the registration of land rights accelerated as contemplated in the peace agreement reached between the Government and FARC in 2016. The land tax system should be strengthened and improved. This could be complemented by an assessment of the current land valuation system and of procedures for land transfer and acquisition (OECD, 2015a).

\section{Gender gaps contribute to inequalities}

Equal participation of both genders in the economy is crucial for growth and well-being of the population. Moreover, increased employment opportunities for women can contribute to a more equal distribution of household earnings (OECD, 2011). Political, social and economic empowerment of women in countries of the Pacific Alliance (Chile, Colombia, Mexico and Peru) has seen remarkable progress in both a historical and global perspective over the past few decades (OECD, 2016a). Major advances have been made in women's participation in decision-making, years of girls' schooling, women's entrance into the labour market and social protection for families. However, gender gaps still remain, in particular for low-income, low-educated and rural women. Gender wage gaps and differences in labour force participation generate inequality of earnings and of household income. Moreover, women are more likely to work in informal jobs, where earnings are often lower and social protection weaker. Women's reliance on informal jobs can widen gender gaps in job quality and in particular, the gender earnings gap exacerbates income inequality (Gonzales et al, 2015).

Colombia has made great progress in reducing gender inequalities in education. Women are relatively well-educated compared to men and even more likely to have a tertiary degree. Colombia has also made significant progress in providing more opportunities for women to develop their careers: female employment rate, measured for women aged 15-64, increased from 46\% in 2001 to $56 \%$ in 2015 nearly reaching the OECD average of 59\% (Figure 3.A and OECD, 2016b). Nonetheless, the gender employment gap, while declining, is still high and remains well above the OECD average as men's employment rates are higher in Colombia than in the OECD (Figure 3.B). Significant gender gaps exist in formal employment, unemployment, wages and job quality. Gender inequalities start early in life, and can compound with age. Colombia's gender gap in the share of young people not in employment, education, or training (so-called "NEETs") is higher than in OECD countries (Figure 4). Gender gaps also exist in the quality of jobs such as average earnings, earnings inequality, labour market security and quality of the working environment (2016b).

The gaps partly reflect childbearing at a young age (OECD, 2016a). Also unpaid time spent on caregiving and housework - tasks overwhelmingly carried out by women across OECD countries remains a significant obstacle to women's labour force participation throughout the life cycle (Miranda, 2011; Ferrant, et al 2014). Mothers have a lower probability of employment relative to men with and without children, and relative to women without children (Frey et al, 2017). Moreover, as in other emerging economies, and to a lesser extent in many OECD countries, women often take care of older or disabled relatives preventing them from taking a full-time job.

The government has acknowledged that narrowing gender gaps will help reduce inequalities and increase long run growth and wellbeing. It has created a special unit in the Presidency for gender (Consejera presidencial para la equidad de la mujer) to identify policy needs. The unit has developed a Equipares programme to change behaviour by providing a quality label for companies that meet good gender practices. It is also offering companies that hire women tax incentives, with stronger incentives for 
violence victims and those over 40 years old. It is also enhancing awareness of the population regarding gender gaps by information campaigns.

Figure 3. Gender gaps in labour force participation are declining but persist in Colombia

\section{A. Colombia's female employment to population ratio is below the OECD average Employment to population ratio of men and women aged 15-64, 2015}

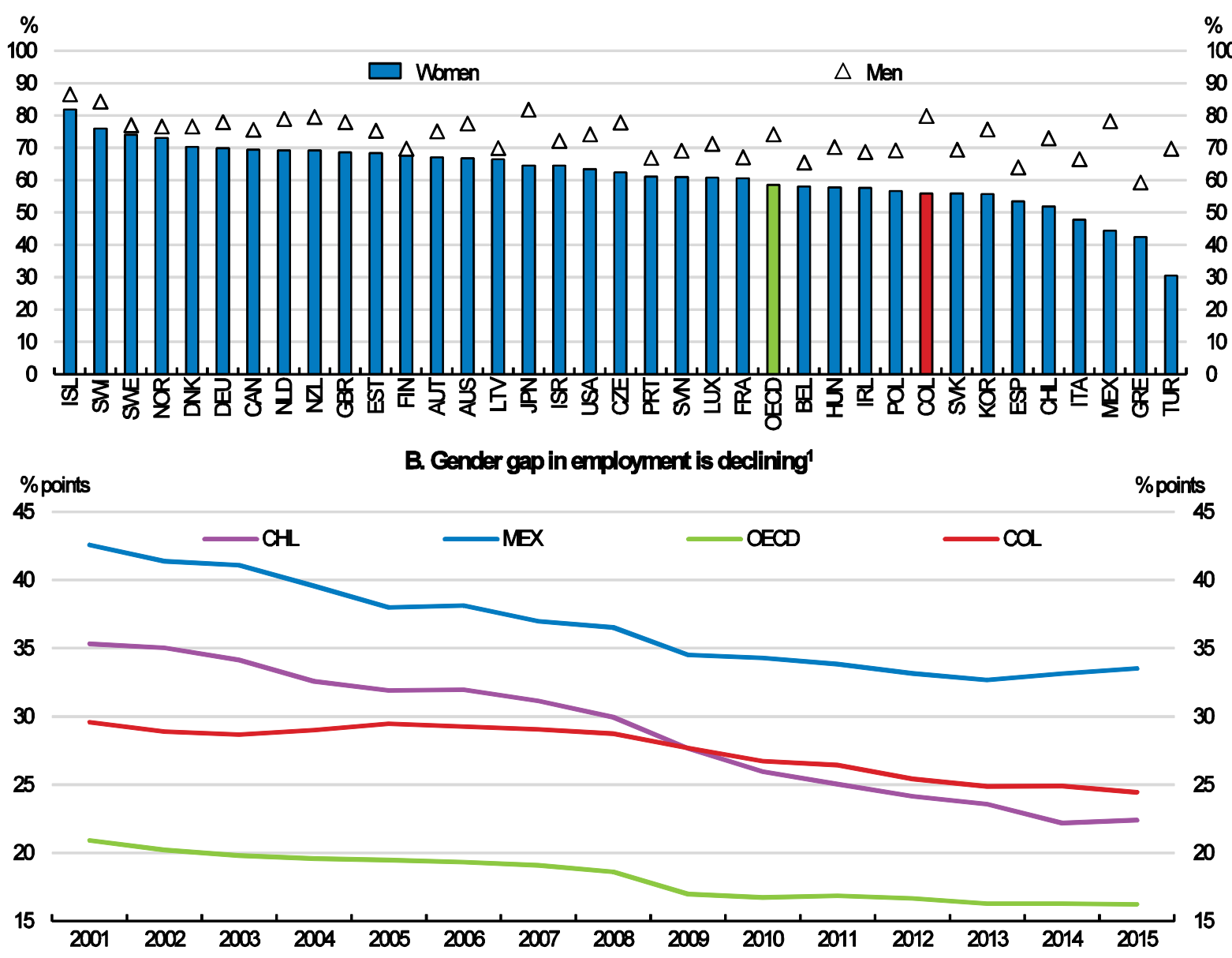

1. Gender gaps in employment are measured as male minus female employment to population ratios, in percentage points. Source: OECD Labour Force Statistics database. 
Figure 4. The NEET rate is significantly higher among women

Percentage-point difference in NEET rates between women and men in 2014

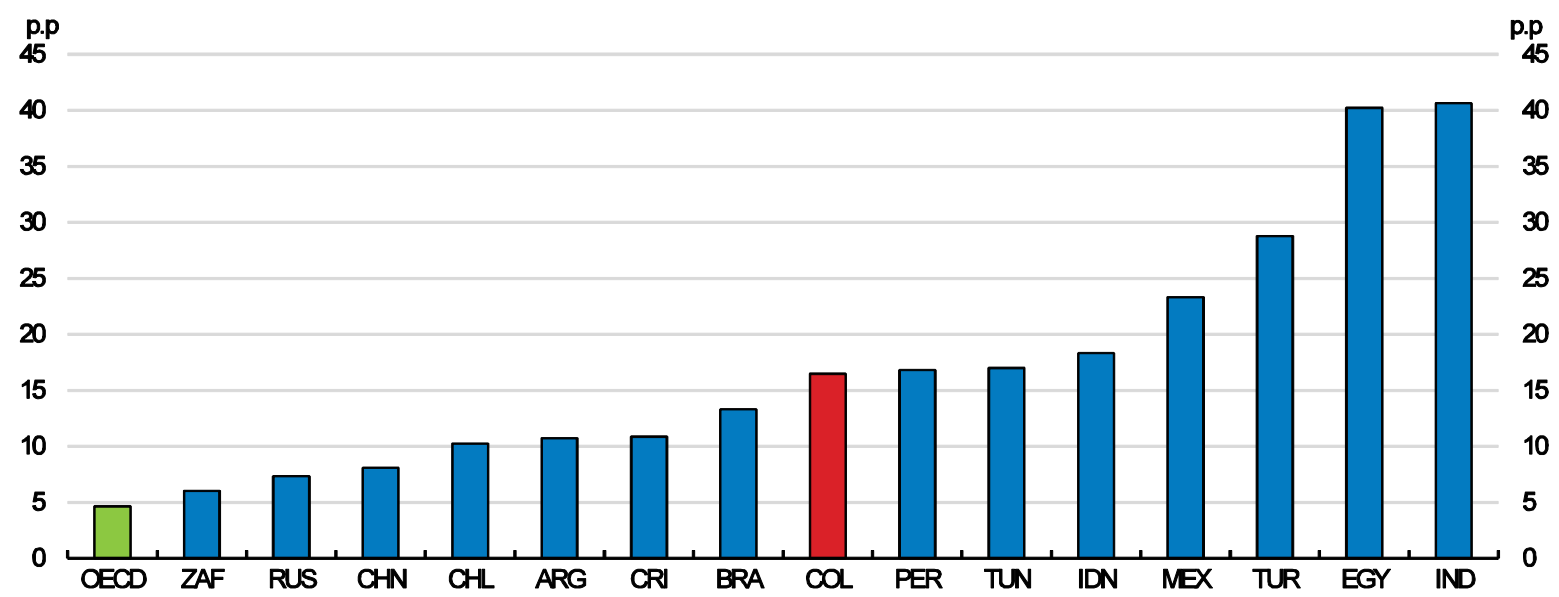

Note: 2010 for China and Tunisia; 2011-12 for India; 2012 for Egypt; 2012-13 for Peru; and 2013 for Chile. For Argentina and Peru, data refer to selected urban areas. OECD is the unweighted average of 33 OECD countries (Japan excluded).

Source: OECD Education Database for Brazil, Chile, Colombia, Costa Rica, Mexico, the Russian Federation, Turkey and the OECD average; ILO STWTS for Egypt and Peru; Census data for China; and OECD estimates based on the EPH for Argentina, the NSS for India, the SAKERNAS for Indonesia, the QLFS for South Africa and the ENPE for Tunisia.

A public commitment towards early childhood education and care (ECEC) is particularly important to ensure that families have options to make the work-life decisions that fit their needs. Affordable access to ECEC increases labour market participation of parents with young children (Baker, Gruber, and Milligan, 2005; Bauernschuster and Schlotter, 2015; Thévenon, 2015). ECEC policies are also important for ensuring children's education, health, and material well-being, as investments made in early childhood have lifelong effects (OECD, 2011 and OECD, 2012a). ECEC has been a priority in recent years in Colombia. Enrolment rates of children from 0 to 5 year-olds have grown from 16 to $41 \%$ between 2007 and 2013 and the government adopted the Cero a Siempre Strategy to provide a framework for the sector.

Colombia should support parents, and especially those with low education levels, and from disadvantaged socio-economic backgrounds, who are often less inclined to give their children a fair chance in education (OECD, 2012a). Poorer children can be helped by providing books and other resources to create a positive home learning environment. The Family modality program provides support primarily in the home and targets pregnant women, breastfeeding mothers and children from birth to two years-old in rural areas. Improving school readiness by expanding the family modality to all disadvantaged areas with well-trained and qualified staff who can effectively engage families and children in learning up to the transition year should be a policy priority.

Financial and social outreach measures could be considered to encourage participation among disadvantaged families. Evidence from Chile's conditional cash transfer programme, Solidarity in Chile (Chile Solidario), which combines cash assistance with psycho-social support for families, succeeded in raising the proportion of children attending pre-school (Vegas and Santibáñez, 2010). 
$40 \%$ of Colombian mothers with children under age five have at least one child in formal childcare (OECD estimates based on DANE, Encuesta Nacional de Calidad de Vida, 2015) compared to 60\% in the OECD (OECD Family Database, 2016; OECD Education Database, 2016). However, this hides disparities between socio-economic groups (see below). Colombia also performs below the OECD average in formal pre-primary school enrolment: in 2013, only $41 \%$ of three- to five-year-olds were in pre-primary school compared to $84 \%$ in the OECD. Colombia has an unmet need for childcare, as $21 \%$ of mothers whose children are not enrolled in formal childcare report that they could use it (Frey et al, 2017).

Colombia has a lower wage gap than the OECD average and many Latin American countries (Figure 5). Gender wage gaps are influenced by women's higher probability of career interruptions, occupational and sectoral segregation, gender preferences (and/or constraints) for shorter or longer paid work hours, employer discrimination, and differences in the unpaid work burden at home, which restrict the time women can spend in paid work (OECD, 2012). Moreover, pay gaps only reflect the differences of observed wages of the employed. Any difference in participation between men and women tends to bias the wage gap estimates as earnings gaps are compounded by lower female employment rates (Frey et al, 2017).

Figure 5. Median gender wage gap of full-time employees, 2010-2015

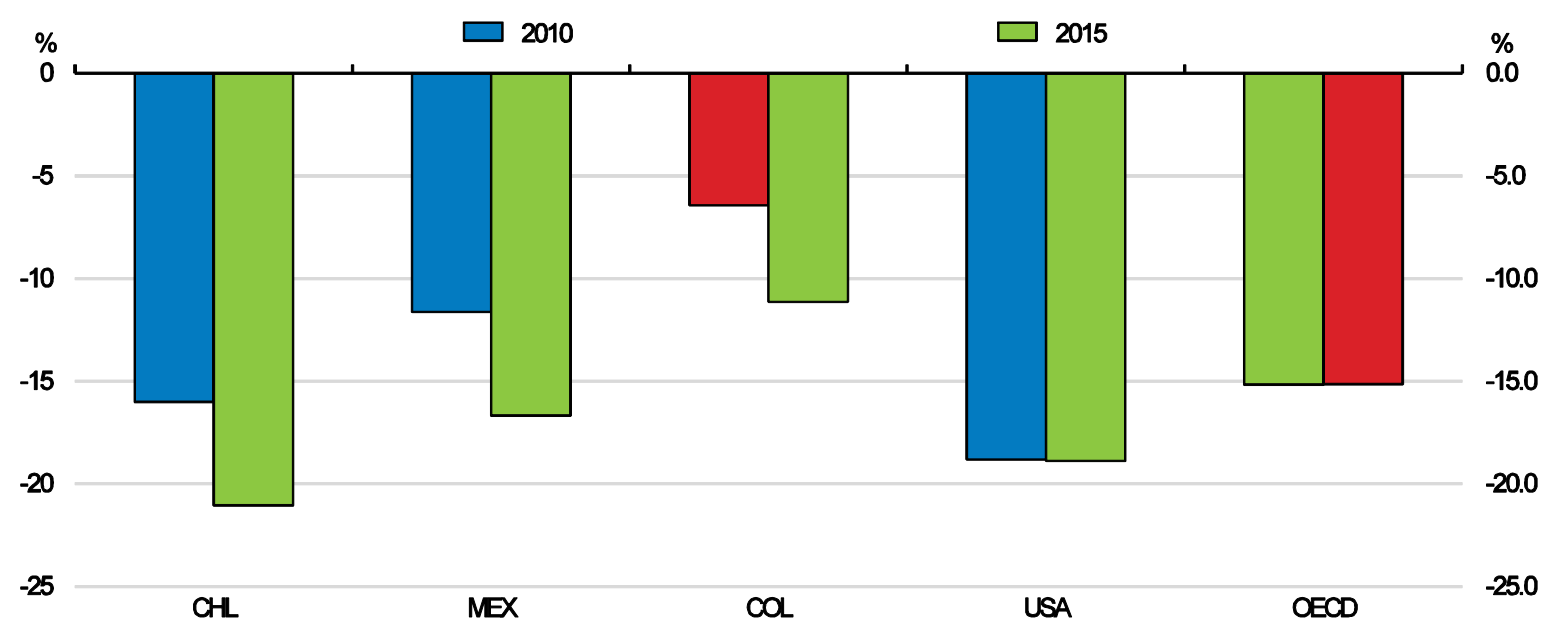

Note: Difference between median wage of women and median wage of men divided by the median wage of men. Data refer to monthly wages.

Source: Most recent year of Encuesta Nacional de Calidad de Vida for Colombia, Encuesta Permanente de Hogares for Argentina, Pesquisa Nacional por Amostra de Domicílios for Brazil, Encuesta de Caracterización Socioeconómica Nacional for Chile, Encuesta Nacional de Ingresos y Gastos de los Hogares for Mexico, The Annual Social and Economic Supplement (ASEC) to the Current Population Survey for the United States.

However, Colombia's relatively low gender wage gap should be interpreted with caution, as crossnational differences in the gap are determined by differences in the composition of the workforce for both men and women. Gender gaps vary by age and educational status. Low-educated women in Colombia earn $7 \%$ less than their male counterparts, while for the highly-educated the pay gap rises to $14 \%$. The highest gap is among holders of an upper-secondary degree.

The relatively small wage gap may reflect selection effects around the type (and number) of women who enter and remain in work. The composition of the workforce is particularly important in countries like Colombia, where the participation gap is high. The most highly-educated women are a small proportion of the female labour force. The small gender pay gap across the entire population is primarily driven by the participation of less educated women with lower wage gaps. The employment rate of women with lower 
education (less than upper-secondary education) was $45 \%$ in 2014, 40 percentage points lower than the one for men. In contrast, $60 \%$ of women holding an upper secondary non-tertiary degree were employed, 27 percentage points less than men with similar educational achievements. Finally, women with a tertiary degree have an employment rate of 79\%, just 12 percentage points lower than that of men (OECD, 2015b).

Gender differences also exist in hours worked. Women are less likely to work full-time than men. The share of women working part-time among the 15-64 year-olds is around 25\%, more than double the share of men. Moreover, in many regions the gender gap in the share of part-time work is more than 20 percentage points (OECD estimates of DANE, Encuesta Nacional de Calidad de Vida, 2015). Taking into account part-time workers, the median monthly gender pay gap is $7 \%$, only slightly higher than the gap for full-time workers. However the gap between the 10\% lowest-paid women and the $10 \%$ lowest-paid men is close to 55\%. This strongly suggests that gaps in hours worked, between low-paid men and women, is one of the main drivers of gender wage disparities.

Sharing the burden of unpaid household chores, childcare and looking after ageing parents more equally between men and women would improve work- life balance for women and men alike (OECD, 2012b). The availability and the costs of childcare should be set at a level that makes full-time jobs profitable for women. Investing in ECEC will not only enable women to work but will also yield important gains for children's cognitive and socio-emotional development, particularly given the poor home environments that Colombian children might face at home (see below). Affordable long-term care facilities are also needed. Enabling parents to make flexible work arrangements and discourage workplace cultures penalising women for interrupting their careers to have children and encouraging excessive hours are key to improve the work-life balance. It is important to raise the awareness of the population regarding gender issues from young ages by information campaign starting from school.

\section{Informality in the labour market contributes to inequalities}

Income inequality in Colombia, as in the OECD and Latin American countries, largely originates from the labour market (Joumard and Londoño Vélez, 2013, Hoeller et al., 2012; López-Calva and Lustig, 2010). Strong economic growth since 2000 improved employment outcomes, especially for women, youth and older workers. However, a large wage premium for those with higher education, high unemployment and many people working in the informal sector enlarge the income dispersion.

The high level of informality exacerbates inequality as informal workers, with low bargaining power, are paid less for the same level of education (Figure 6). Moreover, they often suffer from poor working conditions and lack of social safety nets, which puts them at a high risk of poverty when they lose their job or retire. 
Figure 6. Large earnings gap between formal and informal workers

Gross earnings in thousands of Colombian pesos, 2008-13

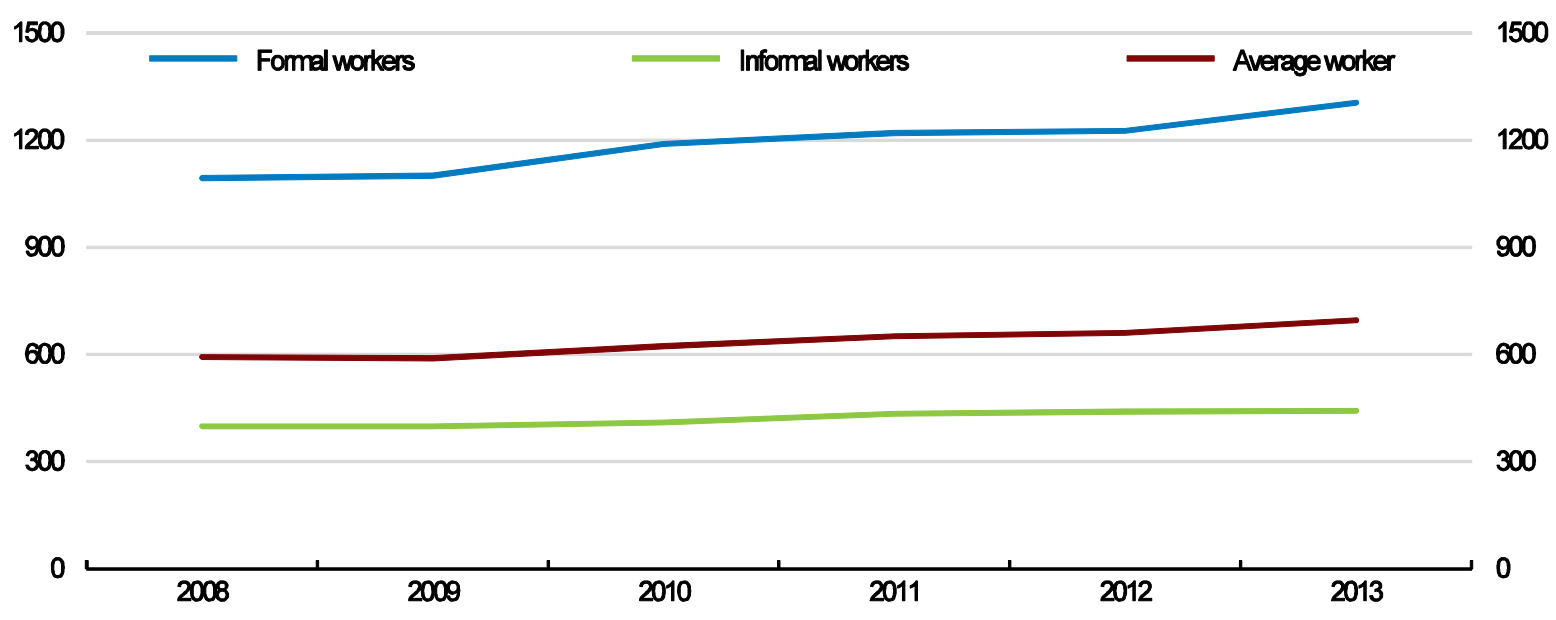

Note: Formal workers are employees and self-employed people aged 15-64 who pay pension contributions. Since formal workers contribute to health insurance ( $4 \%$ of their wage) and pensions (4\%), the net earnings gap with informal workers is slightly lower than shown in the figure. The GEIH survey does not provide information on net earnings.

Source: OECD calculations based on the DANE, Gran Encuesta Integrada de Hogares.

\section{Certain labour regulations contribute to informality}

Informality among employees and self-employed is higher than in many emerging markets and Latin America and Caribbean countries (LAC) (Figure 7). The share of the self-employed in total employment (52\%) is well above the OECD average (17\%) (Figure 8). The majority of the self-employed work in unregistered businesses without access to social security. The informality rate is around $65 \%$, if measured by the share of employees and self-employed not contributing to the pension system (DANE). The large earnings gap between formal and informal workers reflects the higher incidence of informality among low-skilled workers and those working in traditional low-productivity sectors.

Informality is partly due to the high minimum wage, which at $85 \%$ of the median wage is well above the OECD average (Figure 9). As a result, almost half of the total workforce (formal and informal) earns less than the minimum wage. The high minimum wage reduces quality employment prospects for lowskilled workers, youth, and old-age workers especially in less developed regions where productivity is lower. Non-wage labour costs, such as contributions to the Cajas de Compensación, remain high despite recent reforms compared to OECD countries, and encourage informality (OECD, 2015c). Low productivity related to the low qualifications of many workers; lack of awareness about the rights and benefits associated with the affiliation to social security; inflexible social security contributions for certain population groups and sectors; complex procedures for the registration of companies and the affiliation of individuals to social security; and weaknesses in the monitoring process of compulsory contributions to social security also contribute to informality (World Bank, 2010). 
Figure 7. Informality is high

Informality rates among employees and self-employed aged 15-64, latest available year

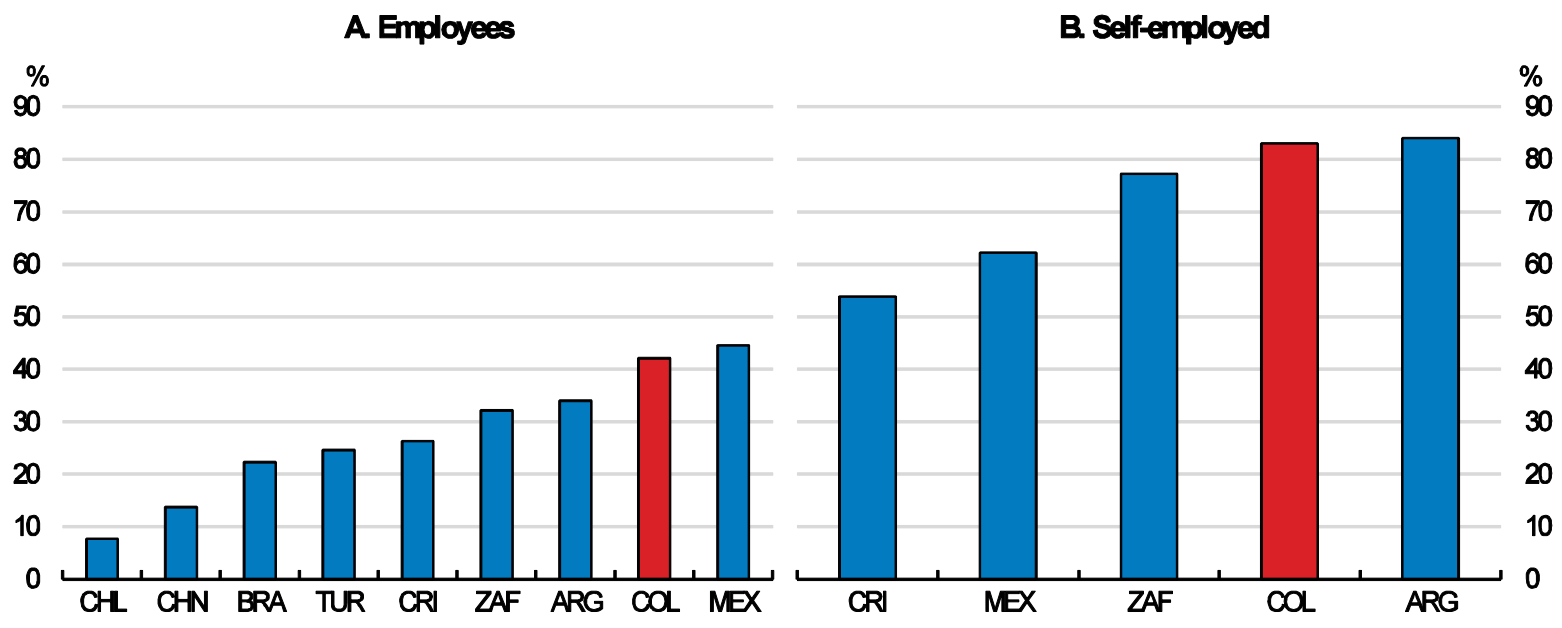

Notes: (1) Informality among employees is defined as the share of employees not contributing to the pension system among the total number of employees aged 15-64 years. (2) Informality among self-employed is defined as the share of self-employed who did not register their business among the total number of self-employed aged 15-64 years. (3) The data refer to 2013 for Colombia and Costa Rica; to 2012 for Argentina, Brazil, Mexico, South Africa and Turkey; to 2011 for Chile; and to 2009 for China.

Source: OECD (2016a).

Figure 8. Self-employment is widespread

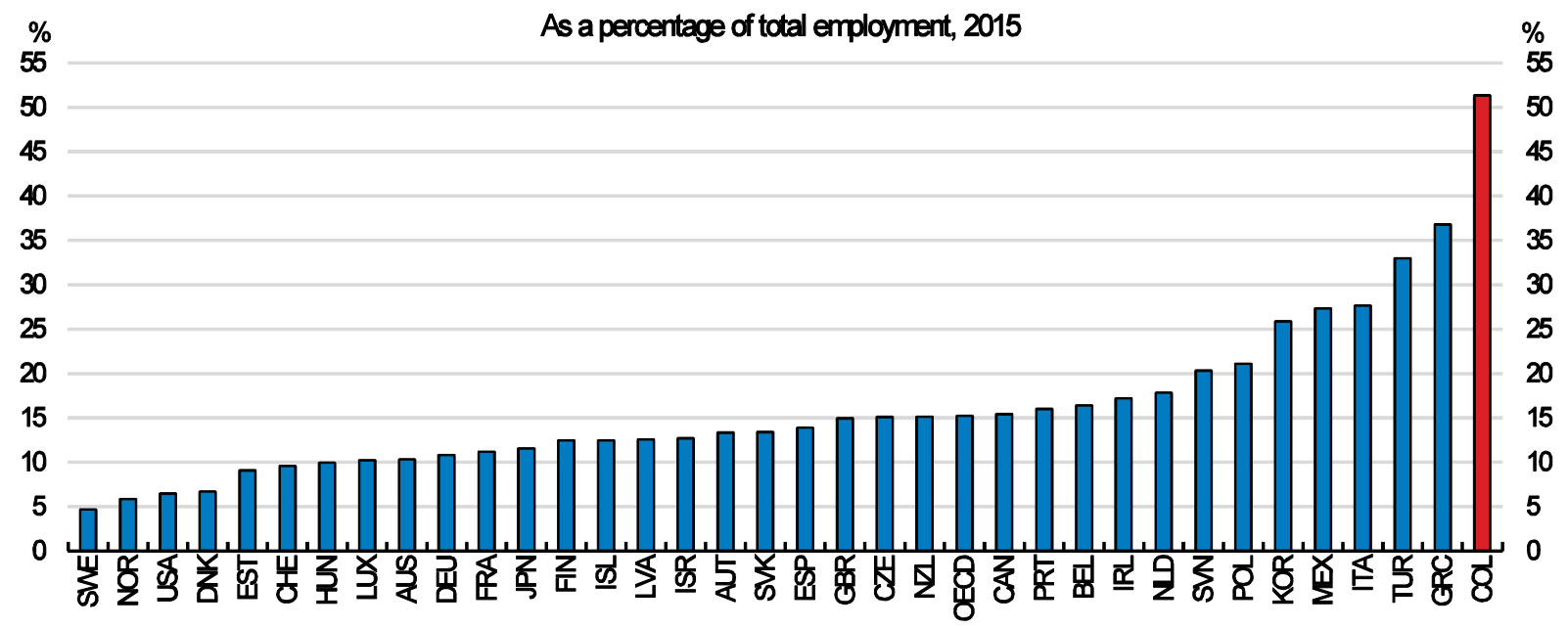

Note: For OECD, data refer to the simple average of data values for all OECD economies for which data are available. For Mexico, data refer to 2013. For New Zealand, data refer to 2014. Self-employment is defined as the employment of employers, workers who work for themselves, members of producers' co-operatives, and unpaid family workers. The latter are unpaid in the sense that they lack a formal contract to receive a fixed amount of income at regular intervals, but they share in the income generated by the enterprise.

Source: OECD Economic Department Database and DANE, GEIH. 


\section{Figure 9. The minimum wage is high}

As a percentage of the median wage, 2014 or latest available year

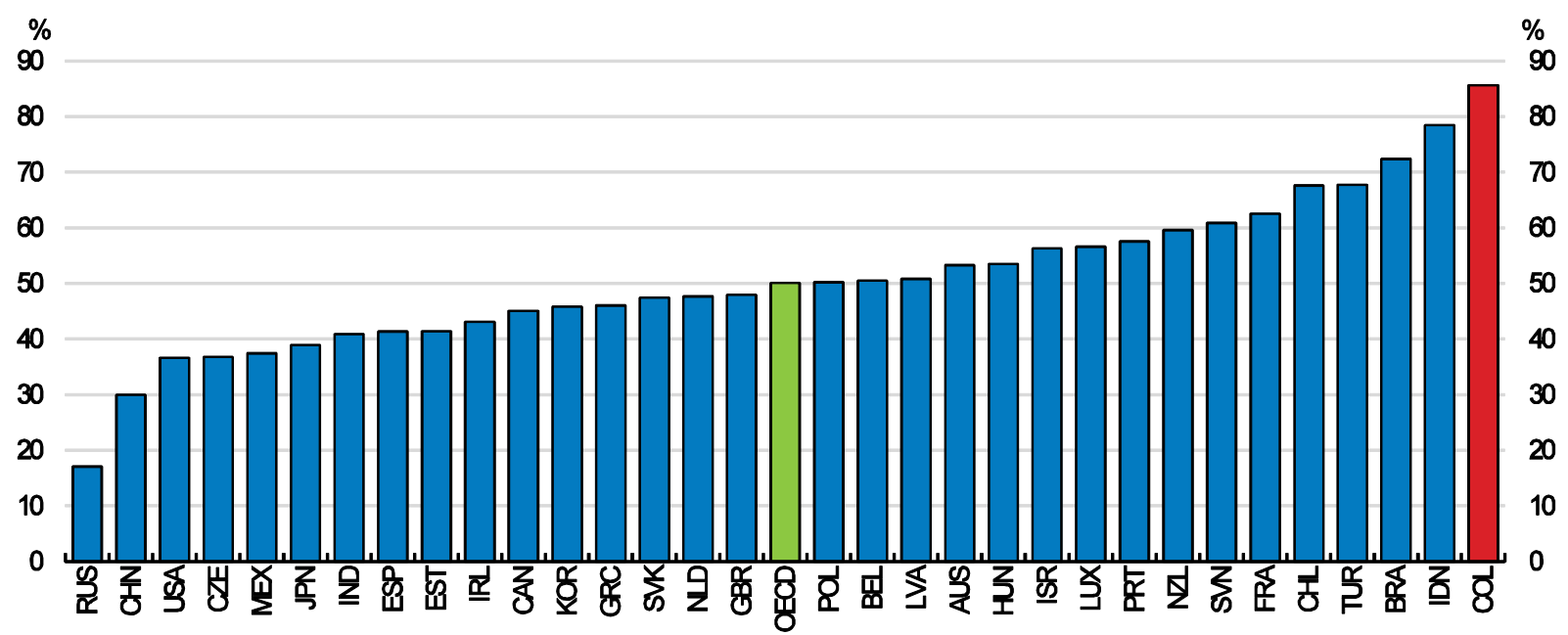

Note:. Missing OECD countries do not have a national statutory minimum wage except for Mexico. Percentage of minimum to average wage for China, Indonesia, the Russian Federation and India.

Source: OECD (2016), Going for Growth database.

The Colombian authorities have promoted labour formalisation. The Formalisation and Job Creation Law of 2010 established a package of incentives to formalise firms and employment. Similarly the tax reform of 2012 significantly reduced non-wage labour costs (various taxes on wages) such as the contribution to vocational training (OECD, 2016c). While the effects of the former seem limited, formal job creation increased after the adoption of the latter (Figure 10). Based on the affiliation to the social security system and on the 13 metropolitan areas, formal jobs would have increased from $40 \%$ of total employment in 2011 to $50 \%$ by end 2016.

A range of new strategies and measures were put in place since 2015 to promote employment and labour formalisation. These include hiring subsidies for 40000 young workers; signature of a memorandum with ILO to formalise rural jobs; launching of a national network of labour formalisation to inform workers about the advantages of social security and recent changes; design of a one-stop-shop for the registration of companies and for different social security systems; extension of rights for domestic workers; accident insurance for self-employed workers; pilot to organise 6-months paid apprenticeships for university graduates in the public sector. The impact of these measures still needs to be assessed. To reduce high informality rates, focus should be placed on further reducing the non-wage labour burden on wages; simplifying the complex procedures for the registration of companies and the affiliation of workers to social security. The creation of a one-stop shop to deal with licenses to open and register a new business will help. Past OECD surveys have recommended differentiating the minimum wage by age and regions and slowing the rate of increase to inflation to increase the gap with average wages. This could help reduce inequalities, promote better job creation, increase productivity and inclusive growth. At the minimum, establishing social dialogue to discuss differentiating the minimum wage by age and regions should be considered. 
Figure 10. Evolution of formal and informal job creation

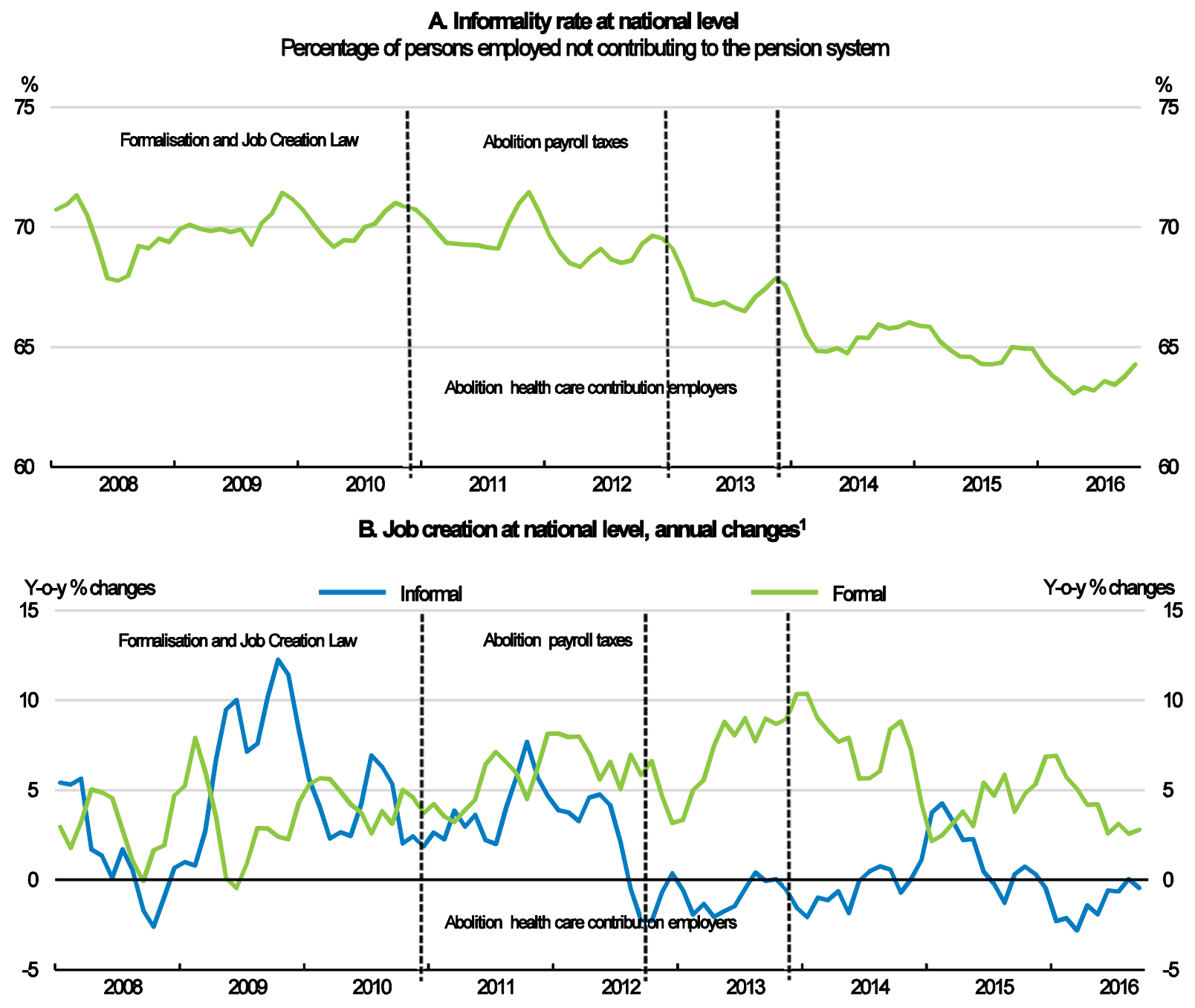

1. Formal job creation is defined as the year-to-year change in the number of workers working in firms with 5 or less workers (including employees and self-employed) contributing to the pension system, while informal job creation is defined as the yearto-year change in the number of workers not contributing to the pension system.

Source: OECD calculation based on GEIH data sourced from DANE.

\section{Some social insurance programmes reduce incentives to formalise}

Some social insurance programmes without a clear link between contributions and benefits also limit formalisation of employment. For instance, the health care system with a contributory scheme for formal workers and a non-contributory scheme for informal ones with almost equal benefits contributes to informality. Moreover, there is a discontinuity in health care coverage when an individual's employment status changes. Workers (or their household members) who are receiving treatment through the noncontributory subsidised system have to submit a request for the continuation of the treatment to the contributory health care regime upon entering a formal job, which may imply delays in ongoing treatments. Conversely, workers who lose their formal job may not be able to quickly regain access to the subsidised health system as the registration process takes time (OECD, 2016c). While universal health coverage is crucial (see below), it would be important to find other sources of funding for the subsidised scheme to 
help employment formalisation. Higher productivity that would support higher growth would help to raise more revenues, which in turn will help sustain increase social spending including health (Olaberría, 2017).

Disconnection between contributions and benefits also affects the family compensation funds (Cajas de Compensación Familiar). Employers contribute 4\% of their wage bill, while an increasing part of the contribution is used to finance social programmes directed to informal workers. As recommended in the last OECD Economic Survey of Colombia in 2015, the government could consider revising the financing of the Cajas de Compensación system. For instance, making voluntary the contribution to the services not available to all formal workers would help formalisation.

\section{Taxes and transfers redistribute little}

The low redistribution in the tax system compared to OECD and many Latin American countries (Figure 11) partly reflects the relatively low overall tax intake. Even if taxes and transfers were more progressive, their impact on inequality would be small. The tax mix is also regressive with heavy reliance on consumption taxes, and regressive exemptions (OECD, 2015c). The redistributive impact of taxation is further reduced by the fact that most income and wealth taxes are paid by firms rather than households. Colombia needs to increase redistribution of income through the tax and transfer system. The introduction of the dividend tax included in the December 2016 tax reform and elimination of the wealth tax will help in that respect. However, keeping the personal tax income base and rates unchanged and raising VAT will reduce progressivity of the system.

\section{Figure 11. The tax and transfer system does little for redistribution ${ }^{1}$}

0.8

O cal $\square \mathrm{CH}$

$\triangle$ OECD

0.6

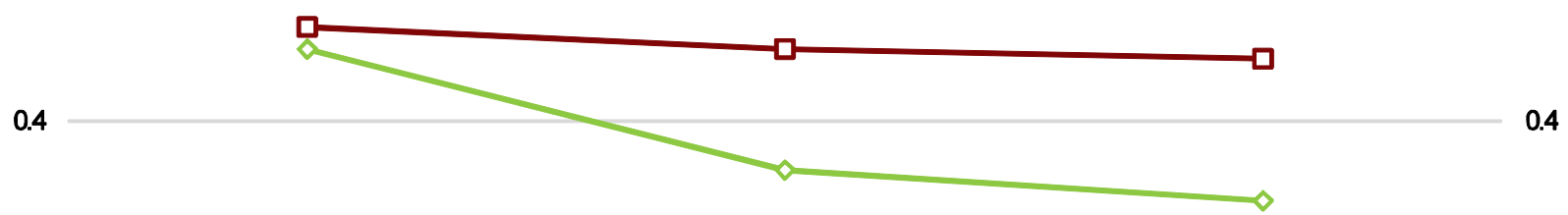

0.2

Market income, before taxes and transfers Gross income, before taxes (and after transfers) Disposable income, after taxes and transfers

1. Gini coefficient by income definition, 2011. Estimates based on OECD Income Distribution Database's definitions. Estimates for Colombia were provided by the National Department of Statistics (DANE) and based on National Quality of Life Survey (Encuesta Nacional de Calidad de Vida, ECV).

Source: OECD (2016a).

\section{The unemployed have high risk of poverty}

Despite improved employment outcomes in recent years, unemployment is still high and the level of allowances too small to protect the unemployed against poverty. In 2013, the government introduced a new unemployment protection mechanism (Mecanismo de protección al cesante). It provides small allowances for some unemployed, a voluntary system of individual unemployment savings accounts, a network of public employment services and active labour market policies (OECD, 2016c). In September 2016, 10\% of 
the unemployed were receiving these allowances partly because of the high share of informal workers without access. The workers are encouraged to contribute to individual saving accounts but as they can withdraw money for other purposes than unemployment (e.g. to finance education or purchase a house), the system is diverted from its primary goal of income protection. The government should reinforce the system by restricting options to withdraw the funds for other reasons than unemployment. Moreover, to help return to the labour market, the income support should be complemented with sufficient funding for employment service providers and active labour market policies which is currently limited (OECD, 2016c), in spite of recent efforts made by the public employment service.

\section{The social system has reduced inequality and poverty but could redistribute more}

Public social spending has increased remarkably since the 1990s due to commitments in the Constitution and higher decentralisation of public expenditure (OECD, 2016c). Nonetheless, it remains low relative to GDP and compared to the OECD average (Figure 12), is not always well targeted and has a very limited redistributive impact. In 2011, work and social security benefits, including pensions, represented the bulk of the spending. In 2013, public social expenditure in Colombia was 13.6\% of GDP compared to $22 \%$ in the OECD on average. Social spending in Colombia has subsequently increased to $14.4 \%$ of GDP in 2015.

Figure 12. Public social spending in Colombia is much lower than the OECD average

As a percentage of GDP by main components, 2013 or latest available year

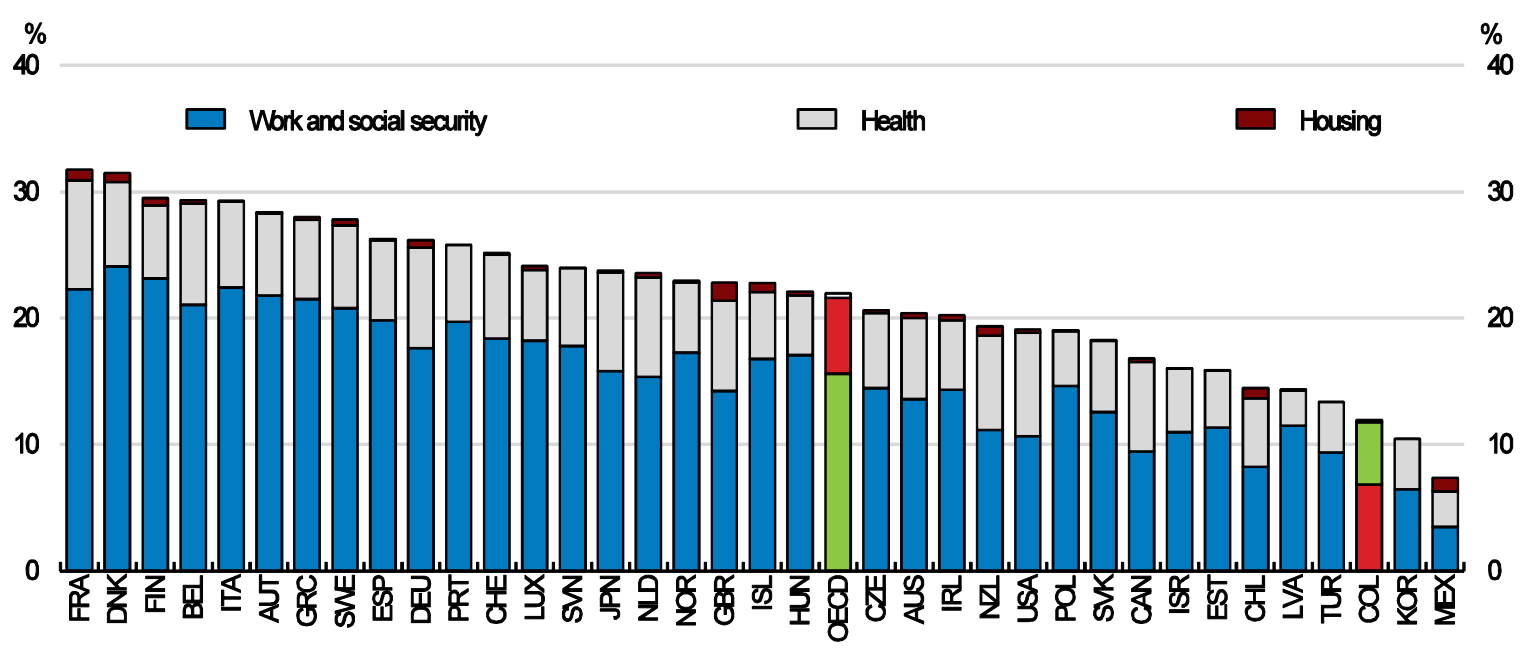

Note: For Colombia, social spending components are based on classification used by Colombian Ministry of Finance; in the case of the health category, data include drinking water supply and environmental sanitation spending. For OECD countries, the SOCX social protection branches are classified as follows: old-age, survivors, incapacity, active labour market programmes, unemployment, family and other social policy areas (Work and social security), health (Health), housing (Housing). For Australia, Canada, Korea and New Zealand, data refer to 2014. For Chile, Colombia and Israel, data refer to 2015.

Source: OECD Social Expenditure Database (SOCX), Ministerio de Hacienda y Crédito Público (2016).

The programmes have reduced inequality and poverty, but they are regressive in absolute terms. In 2008 , the top $20 \%$ of the income distribution benefited from $45 \%$ of social spending while the bottom $60 \%$ got $40 \%$ (Núnez, 2009). More recent data is not available. Education spending contributes the most to the reduction of inequality and poverty, through pre-school, primary and secondary education. In contrast, public expenditure on tertiary education is concentrated in the top quintiles. Health spending also contributes considerably to the reduction of inequality and poverty although it is slightly skewed towards 
the top of the income distribution. The tax reform is expected to increase revenues overall, which gives room to increase social spending.

\section{The pension system is highly unequal}

The level of well-being among the elderly is low compared to OECD countries mainly due to income insecurity. Half of the elderly live below the poverty line. Pensions are estimated to increase the Gini coefficient by 1.63 percentage points (Nunez, 2009) and less than 6\% of pension spending targets households in poverty (Lustig and Melendez, 2014). This reflects the low coverage of the pension system, especially for women and lower-skilled workers, and the weakness of other income support for the elderly (Figure 13). Around $35 \%$ of the population above retirement age receive a pension (Ministerio del Trabajo, 2014) which is low compared to OECD average (around 90\%) and many Latin American countries.

Figure 13. Pension coverage in LAC countries

Percentage of people aged 65+ with a pension

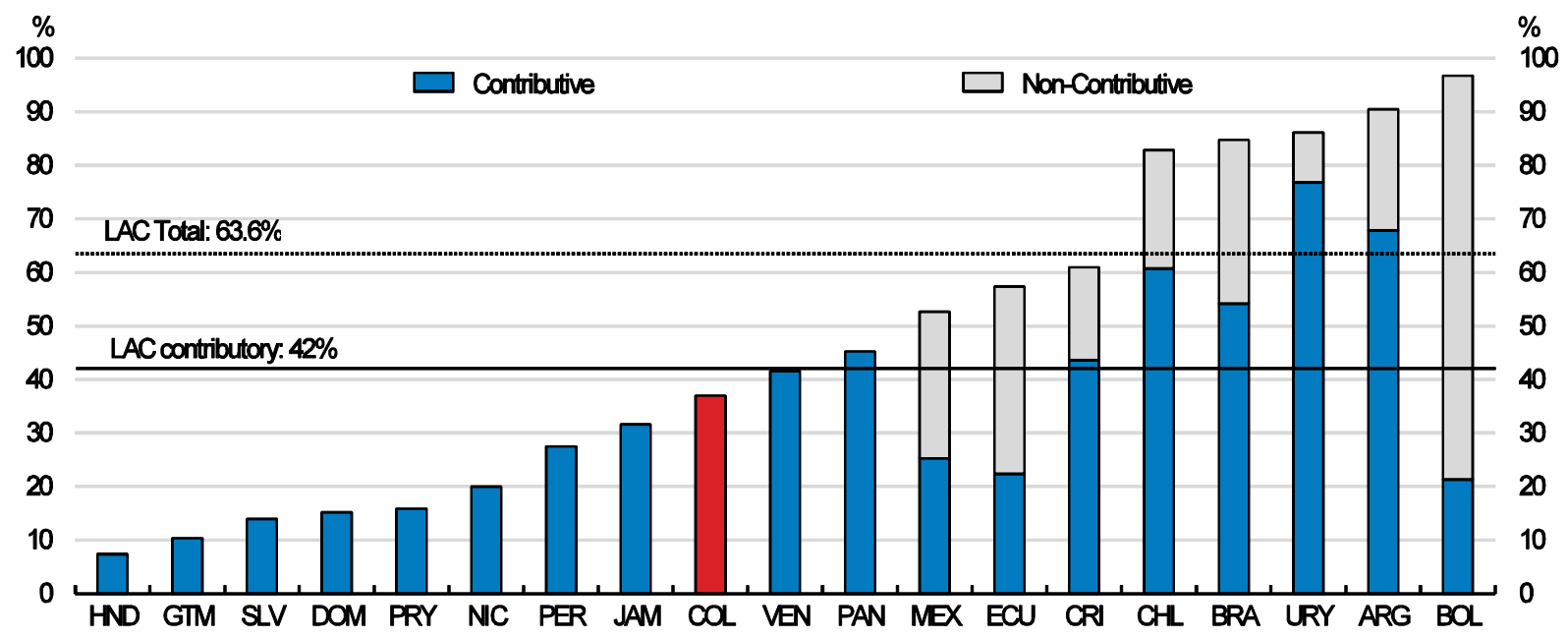

Note: For Colombia, the population covered by Colombia Mayor is not included. LAC refers to the average value of the 19 Latin American countries displayed in the chart

Source: Bosch, Melguizo and Pagés (2013).

The high level of informality and stringent eligibility requirements explain this low coverage. Only formal sector workers who earn at least the minimum wage can contribute to the system. This leaves many people without coverage due to the high incidence of informality. The system comprises two plans (the public defined-benefit plan and a private defined contribution plan) that compete with each other as workers can switch from one to the other several times during their working lives (for an assessment of the system see de la Maisonneuve, 2015). The Constitution requires pensions to be at least equal to the minimum wage, which is costly given its relative high level compared to skills and the median wage. The minimum pension is around $60 \%$ of the average wage while it is below $20 \%$ on average in OECD countries. Pension eligibility is also reduced by the stringent eligibility requirements (around 25 years of contributions), which is long given the relatively low stability low-skilled workers face in the labour market. Currently, only $22 \%$ of the retirement-age population receives a pension from these two plans, which is low by international standards. An additional $15 \%$, judiciary, military and police and teachers, among others, are covered by special regimes. 
The public defined-benefit plan is very generous for the few that benefit from it, contributing to inequality among the elderly. The reference salary to calculate the pension uses the last 10 years of earnings, which is much shorter than in most OECD countries. The replacement rate normally ranges between $65-80 \%$ of the average contribution wage, which is high in comparison with OECD countries, and reaches $100 \%$ for people earning the minimum wage. The system benefits those with steep earnings profiles, frequently those with high education and income.

To deal with the lack of pensions for workers in the informal sector, the government has recently launched the Beneficios Económicos Periódicos (BEPS) programme to extend coverage. The BEPS sets up individual retirement accounts, for which the government subsidises $20 \%$ of individual contributions for low-income households. People can contribute to the scheme even if they earn less than the minimum wage. Thus, in principle, it allows for a contributory old-age scheme without the minimum wage constraint. The reform is welcome, although so far only a few thousand people have joined the system. This may reflect the difficulty lower-income people have to save for old-age.

\section{Old age income support is low}

The government also provides old-age income support for the poor through Colombia Mayor. To be eligible, a woman should be at least 54 and 59 for men, however people over 65 years old are prioritised. The average benefit is about a tenth of the minimum wage, which in relative terms is below that of most OECD countries, and well below the Colombian poverty line. The support is less than $5 \%$ of GDP per capita and total expenditure for the scheme is $0.02 \%$ of GDP, which are below similar support in other LAC countries (Figure 14). The number of recipients of Colombia Mayor has increased significantly in recent years to reach $62 \%$ of the 2.4 million potential beneficiaries. The planned extension of coverage is welcome and should be accompanied by an increase of the benefit.

\section{Figure 14. Social pensions in Latin American countries}

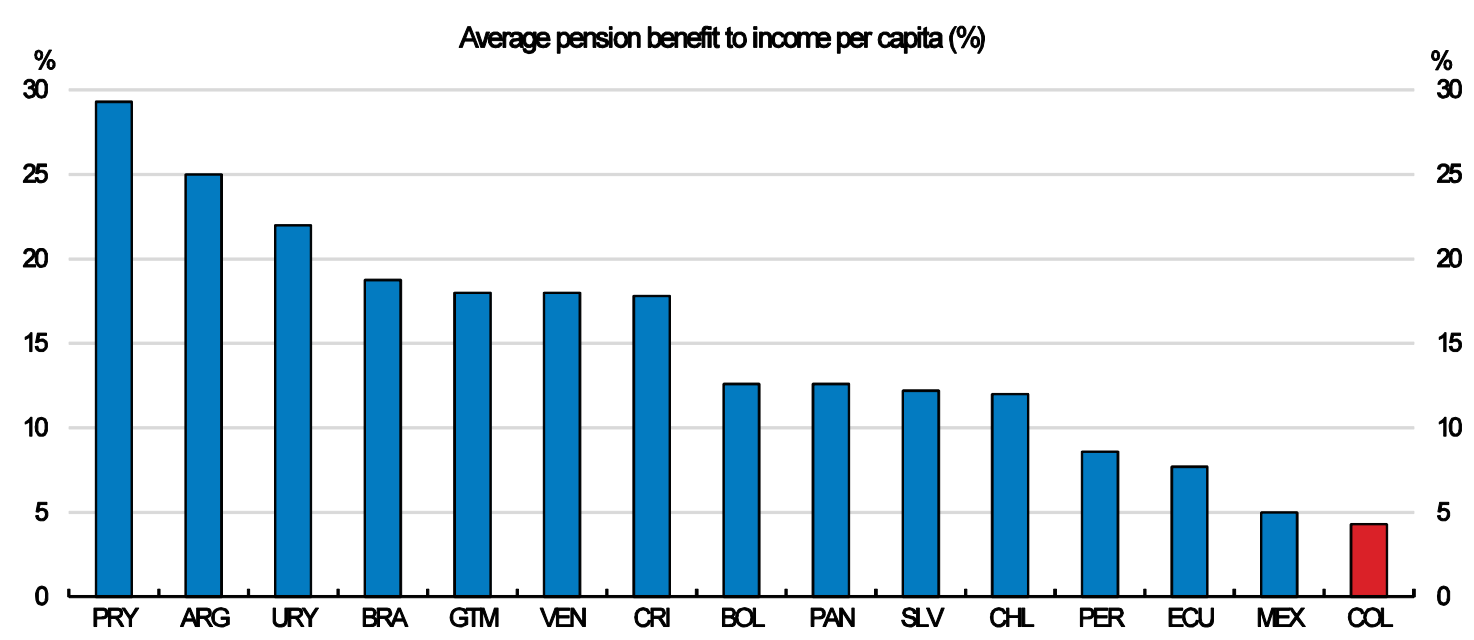

Note: For Brazil, data refer to the weighted sum of average pension benefit to income per capita ratios of two pension programs, Previdencia Rural and Beneficio de Prestacao Continuada. Weights applied are the ratios of beneficiaries in each program to total population aged 65 and above.

Source: Rofman et al. 2013, Social Pension Database HelpAge, Household Surveys and author's calculations.

Pension coverage for all workers can be raised by reforming the two current public and private plans and extending the BEPS. The coverage could be extended, while fiscal costs could be contained, by relaxing the constraint that the minimum pension must be at least equal to the minimum wage. However, this would require a difficult constitutional reform (OECD, 2015c). Another option is to give people who 
reach retirement age with less than the required number of years a partial pension. This retirement payment would be equal to the minimum pension adjusted for the difference between the effective contribution period of the retiree and the mandatory 25 years. Coverage can also be increased by expanding the potential beneficiaries of the BEPS, allowing those earning less than the minimum wage and having no access to the BEPS now due to income limits to contribute. The 2016 Tax reform included the Single tax for small business, which pursues formalization; one of the components of the tax is a contribution to the BEPS, which will allow the small merchants to safe for their retirement.

Coverage can also be increased by reforming the public defined-benefit plan. Lowering the replacement rate towards that of the private system (halving it) would eliminate the arbitrage between schemes and reduce the subsidies to the rich $(\mathrm{OECD} / \mathrm{IDB} / \mathrm{WB}, 2014)$. Including more years of earnings to calculate the level of the pension would raise equity. Equalising the retirement age between men and women - currently at 62 and 57 respectively - would raise female pension coverage through longer contribution periods and higher chances to fulfil the requirements. Gradually moving towards a scheme that increases the retirement age in line with life expectancy would increase long-term sustainability. However, ultimately expanding pension coverage will require shifting more of the workforce to the formal sector, where they will be able to pay contributions.

The complexity of the system and the many adjustments required to make it more equitable and sustainable suggest that a comprehensive pension reform is needed. See (OECD, 2015c) for a detailed proposition. In particular, such a reform should extend the coverage and level of old-age income support (Colombia Mayor). The eligibility to the BEPS and the minimum income support should be expanded to guarantee old-age income for more Colombians (OECD, 2015c).

\section{Health coverage is almost universal but access to quality services remains difficult for the poor and in rural areas}

Colombia has made rapid progress towards universal health coverage over the past 20 years. Out-ofpocket payments have substantially declined (Figure 15) and almost all citizens have access to an equal basket of services whether they are in formal or informal employment (OECD, 2105d). After the reforms in 1993, affiliation increased most rapidly in the poorest quintiles (from 4\% in 1993 to $89 \%$ in 2013) and in rural areas (from 7\% in 1993 to 93\% in 2013). The perception of the quality of health care services has also increased. The share of Colombians reporting that health services overall are "good" or "very good" increased from $78 \%$ of the population in 2003 to $85 \%$ in 2010 with the steepest increase in the poorest quintile. Waiting time for a general consultation has also fallen from 6.4 days in 2003 to 3.8 days in 2010 . Outcomes have also improved: life expectancy at birth reached 74 years in 2014 (from 68 years in 1990) compared to an OECD average of 81 years (75 years in 1990) (OECD, 2016d).

Equitable access to health care services is important as it contributes to greater equality of opportunities (OECD, 2015d). However, given the remoteness of many areas in Colombia, poor availability of health centres and health professionals, deficient transportation and high transportation costs make it extremely challenging to ensure an adequate standard of care quality in all regions (OECD, 2015d). Regional disparities and socio-economic inequalities in access to health care therefore remain. $16 \%$ of the rural population reported foregoing health care needs because of the distance to services, compared to $2.3 \%$ of the urban population in Colombia's 2011 quality of life survey (DANE). Similarly, preventive health care consultations (in the 12 months prior to being surveyed) rose from $30 \%$ in 1997 to $63 \%$ in 2010 in the poorest quintile and from 50 to $79 \%$ in the richest quintile, meaning that the gap only narrowed slightly. 
Figure 15. Health care is relatively affordable

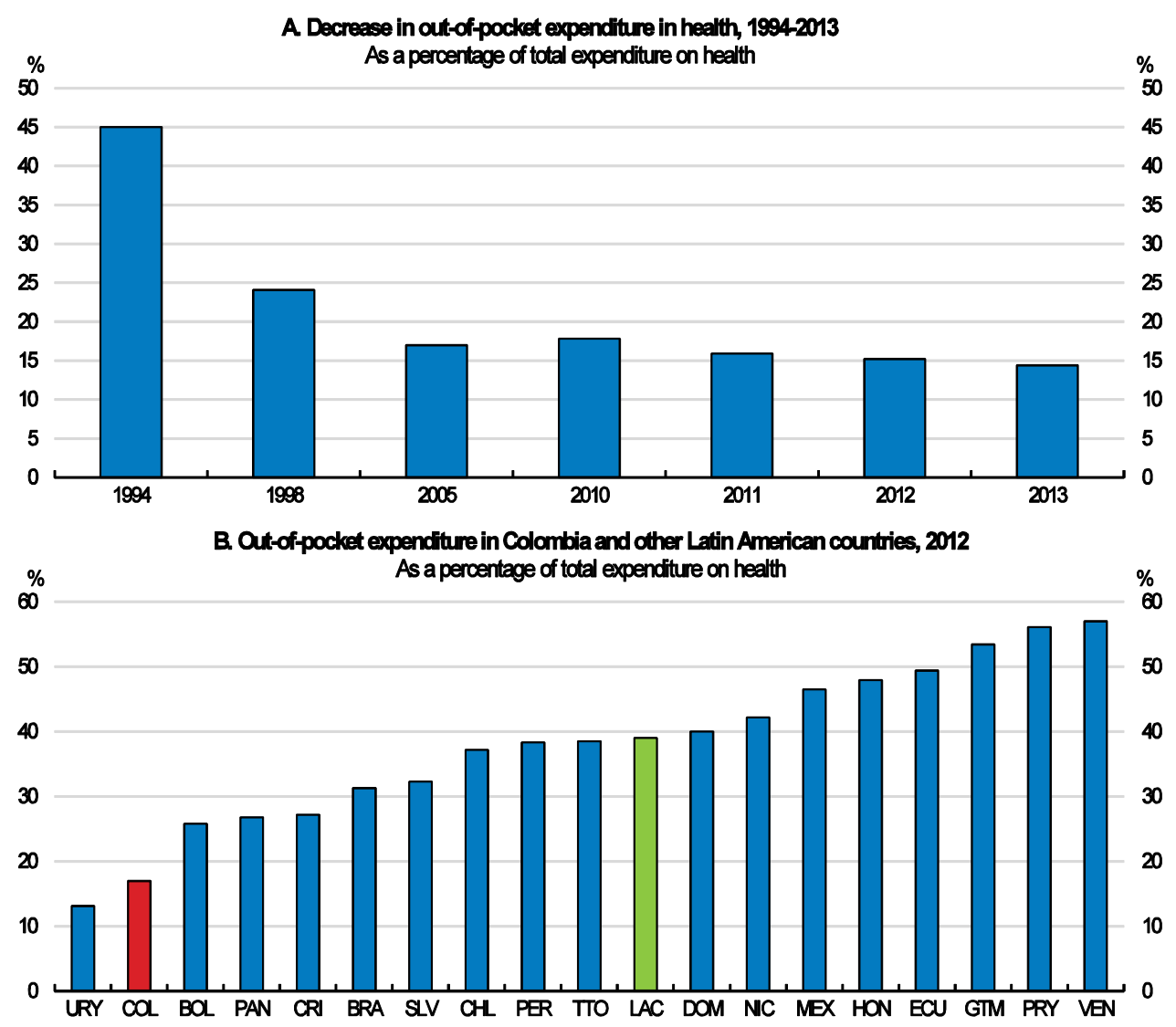

Note: The average for Latin America (LAC) includes those countries whose data are available for 2012, excluding Colombia.

Source: Data provided by Ministry of Health and Social Protection. Health accounts from National Statistics; and WHO (2015), Global Health Observatory (GHO) data.

Health outcomes also differ across regions. Maternal, neonatal and infant mortality rates tend to be higher in rural areas and for specific population groups (e.g. indigenous and Roma people). Infant mortality rates decreased from 70 deaths per 1000 live births in 1970 to 14 in 2014 but rates in some rural departments such as Guainía, Vichada, Chocó, Amazonas and San Andrés remained above 20 per 1000 live born in 2010. Some minority ethnic groups also have higher than average maternal and infant mortality rates, although declining due to improvements in sanitation.

Many rural areas are also inhabited by indigenous communities, who may have beliefs, traditions and models of health care that are substantially different from those in urban areas and OECD countries. The most advanced urban areas also have health care providers using very advanced technologies, as well as good quality public services such as potable water, whereas other cities and rural areas fall behind with limited or no such services (Bernal, 2012). In addition to the direct health effects, the Colombian armed conflict has worsened access to health care, education, drinking water and transportation (ICRC, 2011). With most victims coming from rural areas, the conflict has aggravated geographic and socioeconomic health inequalities.

Under-resourcing in remote and rural areas contributes to inequalities in health services (Figure 16). The density of generalists, specialists and psychiatrists is much lower in those areas. The density of generalist (primary care) doctors, varies from less than 2.5 per thousand inhabitants in Chocó, Guanía, 
Vaupés and Vichada to over 17 in Bogotá/Cundinamarca, Risaralda, Santander and Valle del Cauca (2013 data). Stark differences are also seen in secondary care services. Around one third of all secondary care specialists work from Bogota (OECD, 2015d). The distribution of surgical facilities and hospital beds also varies a lot across districts (Figure 16). Rural departments such as Vaupés, Cundinamarca, Guaviare and Cauca have less than 1 bed per 1000 inhabitants (OECD, 2015d) and Casanare, Chocó, Cundinamarca, Guaviare, Vaupés and Vichada do not even reach half the national average in terms of operating rooms.

Since the introduction of the Sistema General de Seguridad Social en Salud in 1993 (SGSSS, or General System of Social Security in Health) additional resources have been targeted to rural, remote and indigenous populations to compensate both for greater health care needs as well as the increased costs of delivering services in areas of limited accessibility. Other efforts to provide a better service in rural areas have included translating health information into local dialects and using telemedicine (OECD, 2015d). Colombia is also investing in an expanding range of options to use new information technology and communication platforms (ITC). The Ministry of Health and Social Protection and the Ministry of Information Technologies and Communications have a joint programme of work to improve the connectivity of the health sector called Vive Digital to encourage the adoption of ITC in health services. In particular, health providers are encouraged to adopt digital medical records and extend the use of telemedicine. According to 2014 data (Encuesta de Línea Base de Telemedicina), the vast majority of health care providers have some capabilities for tele-consultation, and this has emerged as a useful tool to improve access to primary care services in remote populations at a moderate cost, but its usage should be expanded throughout the country to be truly effective.

A different delivery and financing model is needed in rural and remote areas to achieve levels of access and quality that are comparable to advanced urban settings (OECD, 2015d). Rural and remote areas require a supply-led model of health care, rather than the demand-led model of managed competition that was prioritised by the 1993 reforms. On the ground, however, it appears that relatively little innovation has occurred, other than modest efforts to translate information into local dialects or use telemedicine as described above.

The Ministry of Health and Social Protection has designed a strategy to optimise the assignation process of doctors that aims for a better distribution throughout the country, improving coverage in rural and remote areas. The strategy includes flexibility in hiring conditions, as well as a gradual improvement of wages and result based incentives that aim to encourage primary care clinicians to take up posts in these areas (OECD, 2015d). Despite these improvements the system faces challenges to maintain and improve efficiency and sustainability. Colombia is trying to strengthen primary care and direct the health system away from avoidable use of hospital beds.

Colombia should implement innovative models of service delivery. This will require multidisciplinary teams comprising specialist primary care doctors, nurses, pharmacists and wider professionals. Encouraging health practitioners such as nurses or pharmacists to take on new tasks has been a key element in meeting rural and remote health care needs. Legal obstacles to extending nurses' and other professionals' roles should be removed, for example by developing protocols which authorise nurses to prescribe a limited set of medications under specific circumstances. Colombia already has a telemedicine strategy in place, and this should be extended to cover more medical conditions and geographical areas. For example, there is potential for telemedicine to link specialists in radiology to rural patients and clinicians. Access can also be enhanced by flying specialists in and out of remote areas. Such schemes work particularly well when a visiting specialist works alongside a local clinician. Outreach specialists should be encouraged to act as mentors to local health care workers, building knowledge and confidence, encouraging continuity of care and, most importantly, forging a sustained service network between rural and urban health care providers (OECD, 2015d). In 2015, the Ministry of Health and Social Protection developed the Politica de Atención Integral en Salud (PAIS, or integrated health care policy) which is a 
new model of care that aims to better integrate primary care, public health activities and wider intersectoral action at community level.

Figure 16. Health care resources and access to care remain worse in rural and remote areas

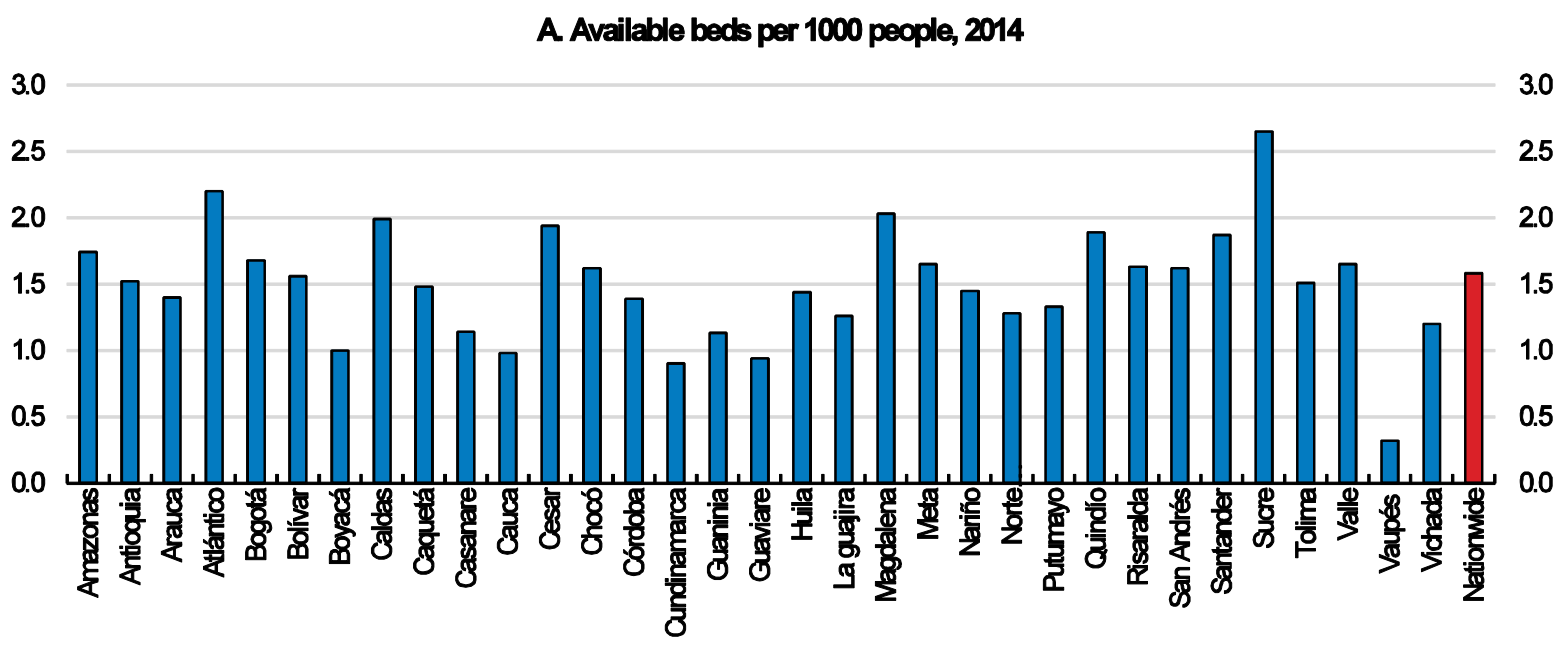

B. Avaliable operating rooms per 100000 people, 2014

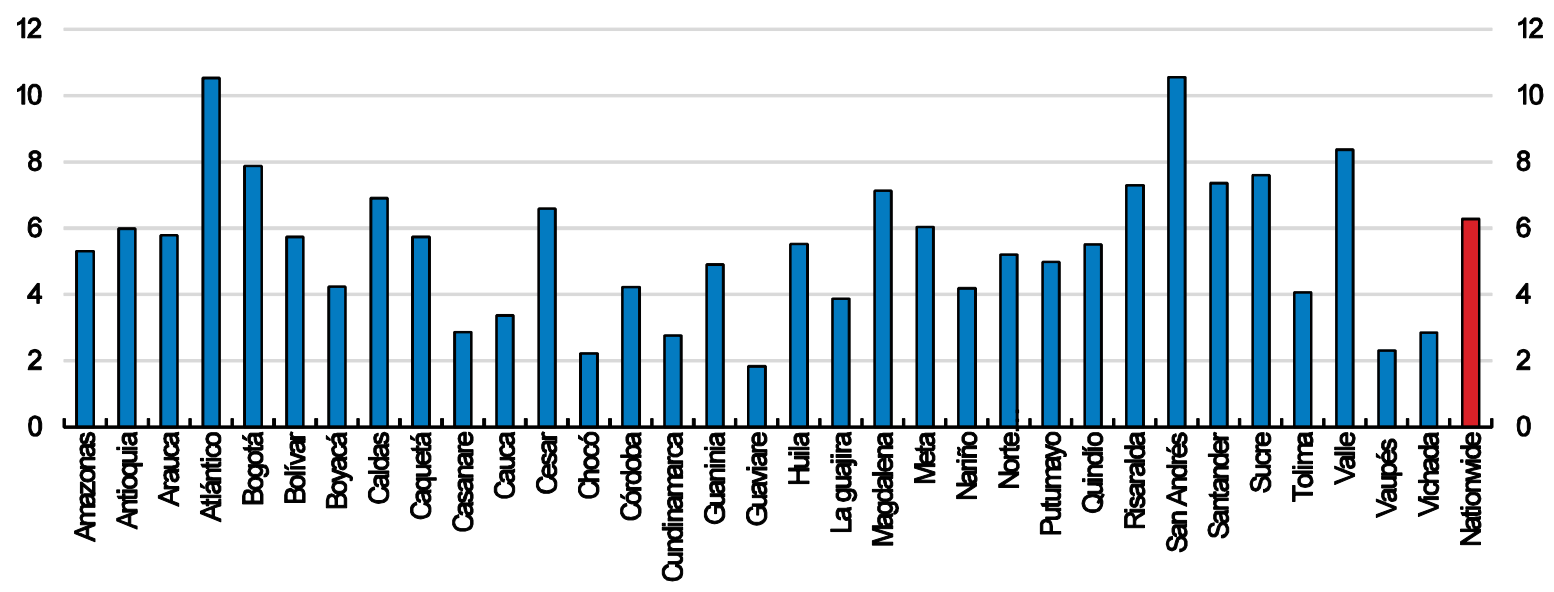

Source: Ministry of Health and Social Protection.

\section{Social welfare programmes are well targeted and achieve positive outcomes}

Colombia has introduced many programmes for the poor and the vulnerable such as Unified Network (Red Unidos), More Families in Action (Mas Familias en Acción) and Youth in Action (Jóvenes en Acción). Red Unidos is a social services intermediation programme to tackle extreme poverty. It doesn't provide cash or in-kind benefits but ensures that families can access available social programmes and services. Mas Familias en Acción is a conditional cash transfer program targeting vulnerable families with children. Jóvenes en Acción aims to ease transition from secondary-education to labour market by promoting enrolment to post-secondary education (OECD, 2016c). A new programme aims to create jobs for the most vulnerable population though the new $4 \mathrm{G}$ infrastructure programme by giving priority to employees from low socioeconomic sectors, after an initial training period. 
These programmes are well targeted and achieve positive outcomes but more resources are needed to raise their impact. Spending could be increased not only on the amount of cash benefits but by undertaking reforms in related policies. For instance, although Familias en Acción has increased school enrolment, the impact on education achievement was smaller due to lack of improvements in the quality of education. Similarly, the impact of Red Unidos was limited due to lack of resources, but also social workers are less qualified in comparison to Chile Solidario; the visits to beneficiary families are infrequent and means are insufficient to respond to eventual increases in the demand for social programmes or services. Furthermore, lack of co-ordination between different programmes, agencies and levels of government reduce the efficiency and effectiveness of programmes (OECD, 2016c).

\section{Low social mobility contributes to inequalities}

In many OECD and Latin American countries income inequality is influenced by low social mobility (Corak, 2013, Azevedo and Bouillon, 2010, Daude and Robano, 2015). Social mobility seems to have worsened in Colombia in recent decades, although it remains hard to measure. Based on the SABER (A Colombian education test) results, Gamboa and Londono (2015) suggest that between 1997 and 2012 equality of opportunities deteriorated.In recent years social mobility through education has improved but it continues to remain low in comparison of other LAC countries and for vulnerable regions and socioeconomic groups (García et al, 2015). Social mobility is in turn influenced by opportunities to improve one's life, which depend on access to and quality of education and ease of participating in labour and product markets in the economy. The armed conflict also has affected upward mobility: evidence shows that victims who suffered more severe episodes of violence have lower hopes and perceive overly pessimistic prospects of upward mobility (Moya and Carter, 2014).

\section{Education enrolment has increased significantly but disadvantaged groups remain behind}

Colombia has made impressive gains in expanding access to education but the quality is still deeply unequal and too many students leave education without the basic skills they need to succeed in life, work and further learning. The latest PISA results show that the percentage of 15-year-old students who don't have the basic skills in science, reading and mathematics is $38 \%$ in Colombia compared to $13 \%$ in the OECD on average and to $23 \%$ and $34 \%$ in Chile and Mexico respectively (OECD, 2016e). Raising the quality of teaching will be vital to improve student learning. Important steps have already been undertaken to ensure that entry into and promotion in the teaching profession are based on merit, and to strengthen the skills of the current workforce. A shared understanding of what it means to be a good teacher would reinforce these efforts, setting high expectations and guiding teacher education, remuneration and appraisal (OECD, 2016e).

Despite increased investment in recent years, public funding for education in Colombia is below that of other major emerging economies in Latin America and per-capita spending is well below the OECD average. In real terms, Colombia currently spends USD 24000 per student from age 6 to 15, which is about half of spending by Costa Rica or one fifth of United States. Colombia needs to invest more and it needs to invest its limited resources in a more equitable way (Heras Recuero and Olaberria, 2017).

Access to education is influenced strongly by socio-economic backgrounds. In Colombia parental education has a strong correlation with individual social mobility. People born in small municipalities, in rural areas, and in the Atlantic, Pacific and South-east regions are the most disadvantaged (García et al, 2015, Ferreira and Melendez, 2012). Low access to education and educational performance in rural areas is explained by the higher rates of poverty, malnutrition, teenage pregnancy, pressure to work, conflict and violence and insufficient infrastructure (CIPI, 2013 and OECD, 2016e). The low attendance rates also reflect poor transitions between levels, high dropout rates and that a significant number of children never enter the education system. Many students also enter school after regular entry age, which 
tend to reinforce high levels of grade repetition and poor academic achievement (OECD, 2013a; Garcia Villegas et al., 2013; Barrera, 2014). Evidence show that the long armed conflict in Colombia has reduced the average education of students residing in areas experiencing conflict by half a year on average (Rodriguez and Sanchez, 2012).

Socio-economic background, geographic location, ethnicity and gender still heavily determine the educational opportunities of Colombian children. According to Colombia's Demographic and Health Household Survey 2009-10 a student from the poorest socio-economic level has a school life expectancy of 6 years, which is half that for an individual from the wealthiest socio-economic level, and is much more likely to be out of school (Garcia Villegas et al., 2013; UNESCO -UIS, 2015). PISA 2015 results also show that Colombia has one of the lowest percentages of resilient students compared to OECD countries, which means that few disadvantaged children overcome their background to achieve high results (OECD, 2013b and Figure 17).

Figure 17. Share of resilient students across OECD and LAC countries, 2015

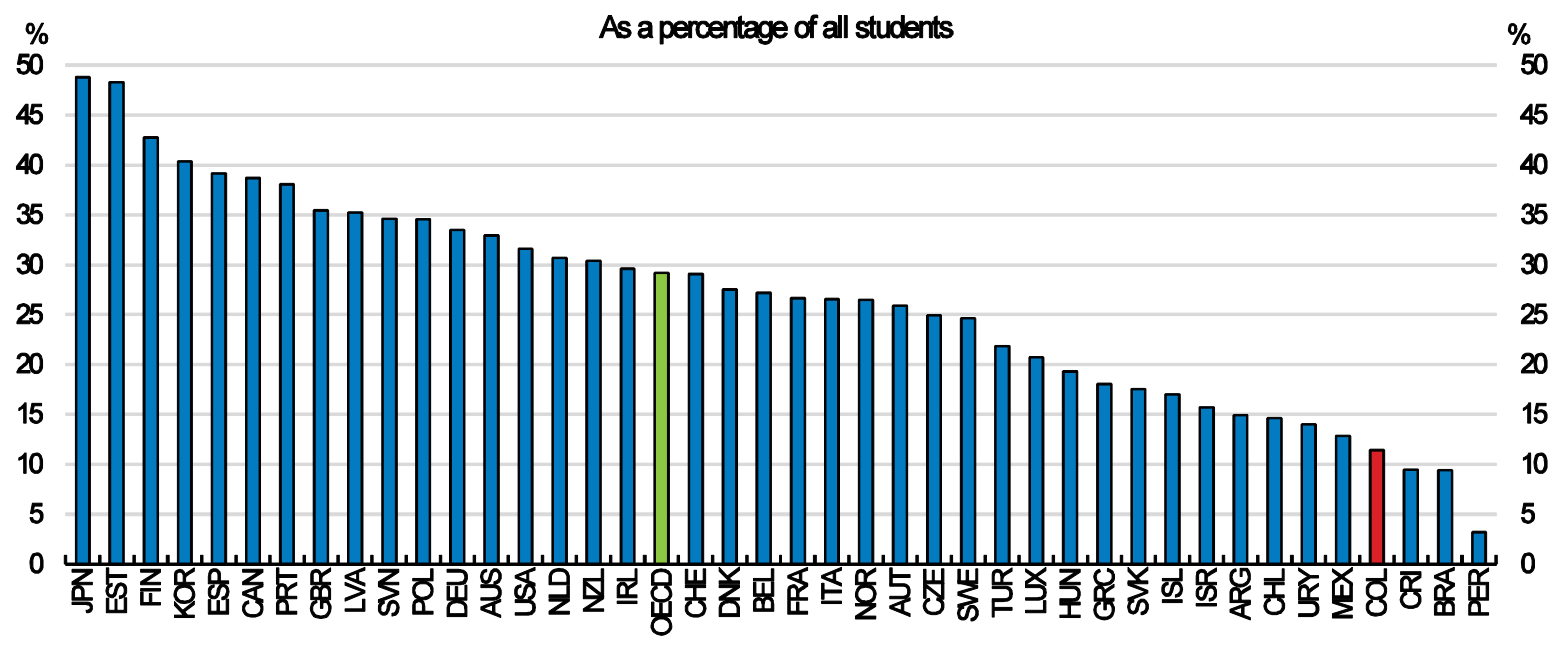

Note: A student is classified as resilient if he or she is in the bottom quarter of the PISA index of economic, social and cultural status (ESCS) in the country/economy of assessment and performs in the top quarter of students among all countries/economies, after accounting for socio-economic status.For Argentina, data refer to the Autonomous City of Buenos Aires.

Source: OECD, PISA 2015 Database, Table I.6.7.

Over the past two decades, governments have sought to increase education participation and performance among poor and vulnerable students. The Government prioritised the expansion of ECEC services for vulnerable and disadvantaged families, in particular to address the high level of child poverty. Funding policies, such as conditional cash transfers aimed at improved equity of access in primary and secondary education. Measures were also targeted to vulnerable groups, such as ethnic communities, children with special educational needs, individuals affected by violence and rural populations. Flexible school models, ethnic education developed in collaboration with the local community, school meals and school transport have also helped to reach disadvantaged groups. To improve poorer children's access, education was made free from the transition grade (grade 0 for 5 year-old children) to the end of upper secondary education in 2012. However, indirect costs such as transport and learning materials remain (OECD, 2016e). In 2012, they were estimated to represent 2.7 monthly minimum wages per year in urban areas (CLADE, 2014). Major investments in infrastructure and education resources have also been undertaken. Major reforms of the teaching profession have been implemented and a strong evaluation system established. 
Enrolment increased in every level and region but remains behind those in OECD and is similar to other Latin American countries. Participation in early childhood education and care (ECEC) and tertiary education more than doubled to $40 \%$ and $50 \%$, respectively, in the last decade. However, enrolment in ECEC remains low compared to OECD countries. The participation rate of 3-year-old children (48\%) is much lower than the OECD average (70\%). Weak provision and lack of awareness of the importance of ECEC are main factors explaining the low enrolment (Alvarez et al, forthcoming and Bernal, 2014) and access remains out of reach for many poor children, especially in rural areas (Álvarez et al., forthcoming; Figure 18).

Figure 18. Participation rates in ECEC, by socio-economic level (2012)

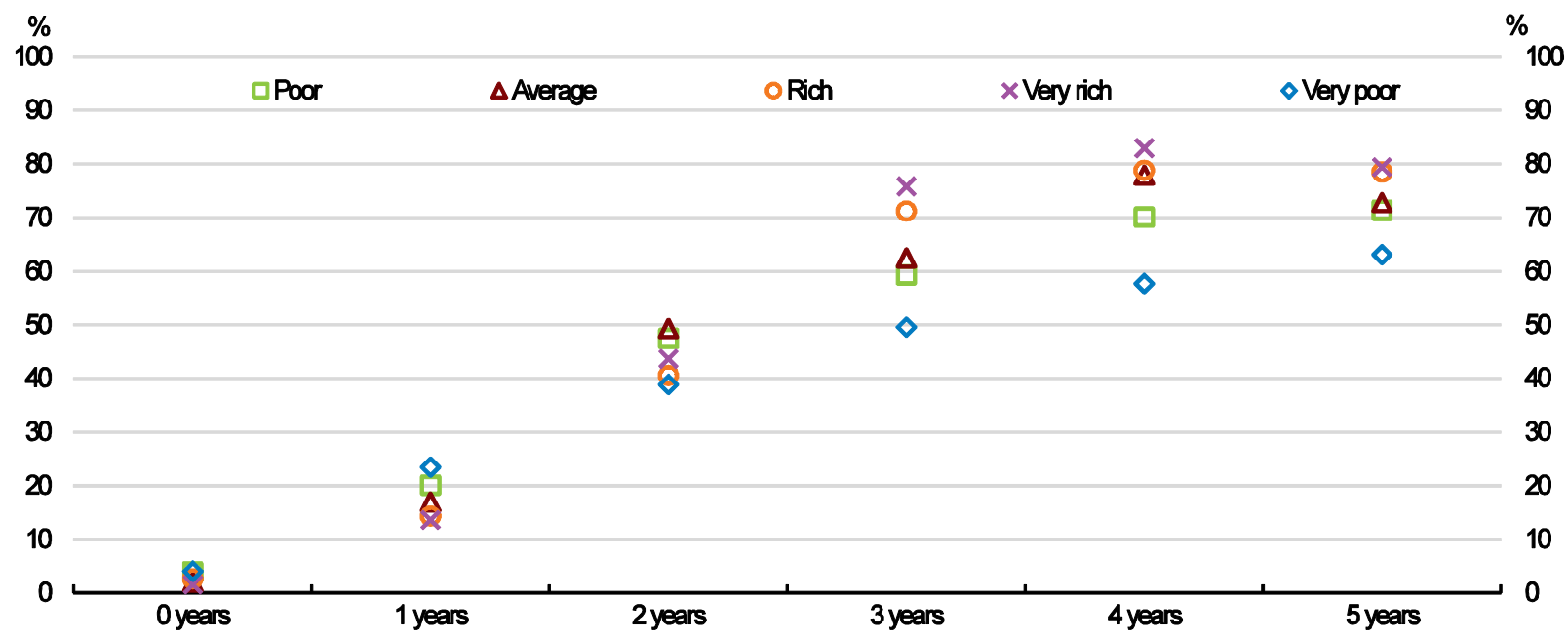

Source: Bernal, R. (2014), "Diagnóstico y recomendaciones para la atención de calidad a la primera infancia en Colombia”, Cuadernos Fedesarrollo, No. 51, Fedesarrollo, Bogotá, Colombia,

www.fedesarrollo.org.co/wp-content/uploads/2014/04/debate_pres_2014_cuad51.pdf

The number of people having attained upper secondary education (USE) remains low compared to OECD countries (Figure 19). Colombia committed to achieve universal compulsory USE by 2030. The forces drawing students out of the classroom are multiple and complex, and vary across regions and between rural and urban areas. The 2010 National Dropout Survey identified financial pressures and the low perceived value of USE among the major factors behind students dropping out (MEN, 2013a). A significant proportion of secondary students combine work and study. The opportunity costs of upper secondary education are high for students from low socio-economic backgrounds and they often choose to work in the informal economy (OECD, 2016e). Alongside high opportunity costs, factors that play a particularly important role at the upper secondary level include teenage pregnancy, violence (inside and outside the classroom) and distance to school. In 2015, $42 \%$ of the children aged 5+ had a commuting time of between 10 and 20 minutes while $23 \%$ spent more than 20 minutes in transport (DANE, Encuesta Nacional de Calidad de Vida, 2015).

In secondary education measures were taken to facilitate the enrolment of students from disadvantaged families, improve the relevance of upper secondary education and, where necessary, help students continue their education whilst working. The main challenge of USE is to shift a system built to prepare a minority of students for university towards an inclusive system that responds to diverse students' aspirations and backgrounds. The abolition of tuition fees has been a very important step for the involvement in USE. 
Figure 19. Share of adult population that has attained at least upper secondary education, 2014

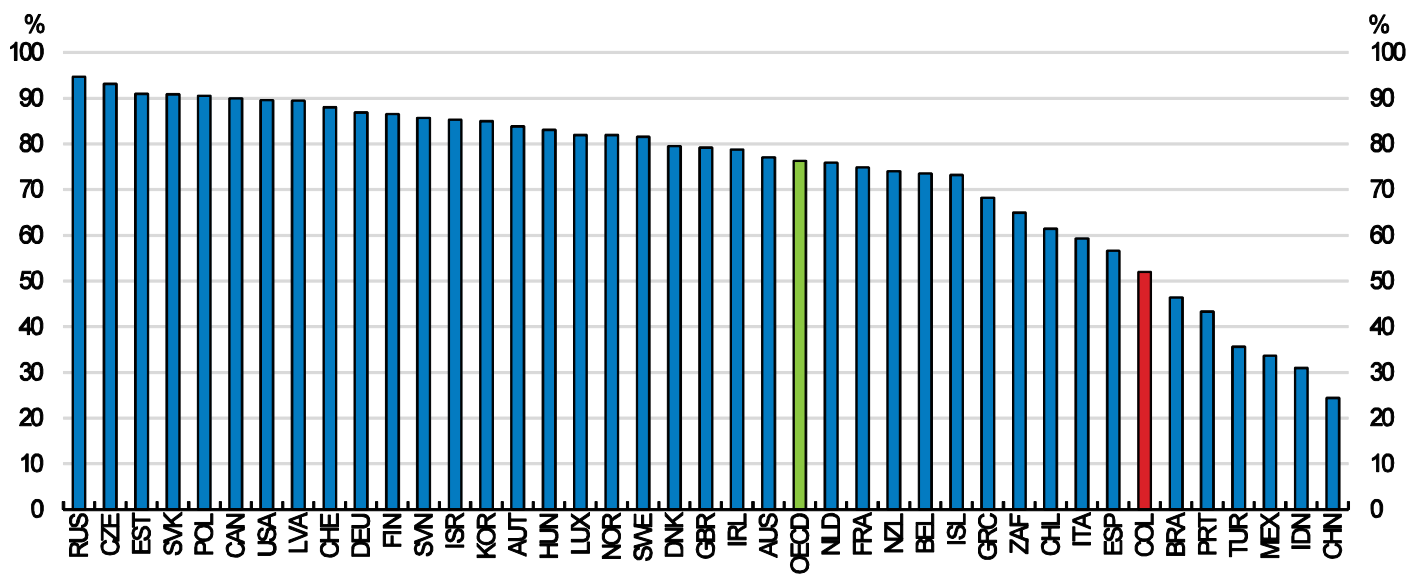

Notes: In most countries data refer to ISCED 2011. The countries with data that refer to ISCED-97 are: Brazil, Indonesia, the Russian Federation, Saudi Arabia and South Africa. See the description of the levels of education in the Definitions section. OECD data point refers to the OECD average.

1. Brazil, Chile, France, the Russian Federation, Saudi Arabia: Year of reference 2013.

2. The United Kingdom: Data for upper secondary attainment includes completion of a sufficient volume and standard of programmes that would be classified individually as completion of intermediate upper secondary programmes $(18 \%$ of the adults are under this group).

3. China: Year of reference 2010.

4. Indonesia: Year of reference 2011.

5. South Africa: Year of reference 2012.

Source: OECD (2015), Education at a Glance 2015: OECD Indicators, OECD Publishing.

Colombia made progress in enrolment in tertiary education, with gross enrolment rates doubling between 2004 and 2013. The enrolment rates are slightly above other leading Latin American countries except Chile- and have expanded faster than these countries. Nonetheless, it remains low compared to OECD countries. In tertiary education also students from low socio-economic backgrounds and rural and remote areas have lower attendance. In 2011, while 53\% of young people from Colombia's richest quintile were enrolled in tertiary education, they were only $9 \%$ in the poorest quintile.

The Colombian government's new flagship policy to help students from low-income backgrounds to access high-quality tertiary education is the new Hard Work Pays Off (Ser Pilo Paga) scholarship programme. It grants scholarships to 10000 students a year for 4 years from 2014 in terms of loans and grants which cover their full tuition and living costs. The loans from Instituto Colombiano de Crédito Educativo y Estudios Técnicos en el Exterior (ICETEX) are also helping many students from poorer families access tertiary opportunities they could never have had otherwise. The percentage of students with financial support has risen over the years, from less than 5\% in the first semester of 2002 to $20 \%$ in the second semester of 2014 (MEN, 2015a). The main Vocational Education and Training provider is the National Training Service (Servicio Nacional de Aprendizaje, SENA) which provides the majority (58\%) of technical and technological programmes at the tertiary level. Many of the disadvantaged students pursue their studies in SENA. This institution will have a major role to play in the post-conflict era (OECD, 2016e). 


\section{Enhancing education opportunities can be tackled with targeted policies}

Raising the quality of education remains a priority in Colombia. The lack of a national curriculum framework for basic and upper secondary education makes it difficult for teachers, schools and students alike to direct their efforts towards higher standards. Raising the quality of teaching will be vital to improve student learning. Important steps have already been undertaken to ensure that entry into and promotion in the teaching profession are based on merit, and to strengthen the skills of the current workforce (OECD, 2016e).

It is particularly important to raise parent's awareness of the importance of ECEC for social mobility (see above). Improving schools, particularly disadvantaged ones, is vital if education is to be an engine for inclusive growth and social cohesion in Colombia (OECD, 2016e). The national transfer system (SGP) should ensure that all schools receive at least the minimum resources required to provide quality learning opportunities. Greater consideration should be given to the level of disadvantage of students and schools in the most challenging contexts to provide teachers with more resources to support their students (OECD, 2016e). Finally, external assessments need to provide schools with better tools to foster improvements.

In secondary education, further measures are needed, such as raising the amount of allocations for those in Grade 11 with higher opportunity costs of staying in education and differentiating payment rates by income groups or other measures of living standards (OECD, 2016e). In tertiary education, public funding to support access for low-income students, either through loans or scholarships, needs to be increased and targeted on those with the greatest financial need. The ICETEX loan conditions could be more flexible for students from very low-income families or rural areas and stricter for those with less financial need.

A way of reducing the regional disparities is a better use of distance learning. In tertiary education, Colombia needs now to increase the enrolment to move closer to the OECD average and raise the quality of its education for everyone (OECD, 2016e). Disadvantaged students should also be provided with better career information to support their choices, make the admission process more transparent to give them a fairer chance, take action against the large number of poor quality universities which might not give them any returns to their financial efforts, or better integrate the VET sector - and the SENA in particular- into the tertiary system as they are more likely to opt for these type of studies.

\section{Labour market policies can also affect social mobility}

Easier employment protection for regular contracts correlates with a looser link between parental educational background and children's wages in European OECD countries. The explanation of these findings is not straightforward. One hypothesis is that stricter employment protection on regular contracts is used by protected workers (so called "insiders") to claim higher wages (Lindbeck and Snower, 1988; Garibaldi and Violante, 2005), at the expense of the unemployed and precarious informal workers (so called "outsiders"). To the extent that individuals from advantaged backgrounds are more likely to be among the group of "insiders", while individuals from less advantaged backgrounds are more likely to be among "outsiders", strict protection may increase the relative wage differential between the two groups. In turn, an increase in wage inequality may translate into higher intergenerational wage persistence (Causa and Johansson, 2009). Overall, the Colombian employment protection legislation is in line with those in OECD countries, but fixed-term contracts and subcontracting through temporary work agencies (TWA) is widespread. While this provides flexibility for firms to adjust their workforce to changing economic circumstances, it means high degree of job insecurity for the workers involved. While Colombia has very flexible regulations on fixed-term contracts and rather strict rules on TWA employment, the shares of both types of contracts in total employment are high. Moreover, transitions from informal to formal employment are very low, and those who manage to move to the formal sector are more likely to work 
under a fixed-term contract than a permanent one, which in turn carries a higher risk of falling back into informality or unemployment. Weak enforcement of the employment legislation further contributes to labour market duality. It will be important to strengthen labour law enforcement and raise fines for labour law infringements related to social insurance (OECD, 2016c), however almost 50\% of the employed are self-employed and so are not covered by labour legislation.

\section{Low financial inclusion is contributing to inequality}

Despite steady improvements, financial inclusion is still low compared to OECD and Latin American countries (Figure 20). This may contribute to higher poverty and income inequality (Park and Mercado (2015), Burgess and Pande (2005), Allen et al. (2013)). Physical infrastructure, the number of access points for financial services such as commercial bank branches, points of sale and ATM machines has increased but is still below OECD and LAC economies. Moreover, the costs are still high and probably excluding many poor individuals. For instance, the number of ATMs per 100,000 adults increased from 24 in 2007 to 40 in 2015 but is still below the OECD average of 96 and the LAC6 average of 73 (IMF, 2016).

\section{Figure 20. Financial inclusion is low}

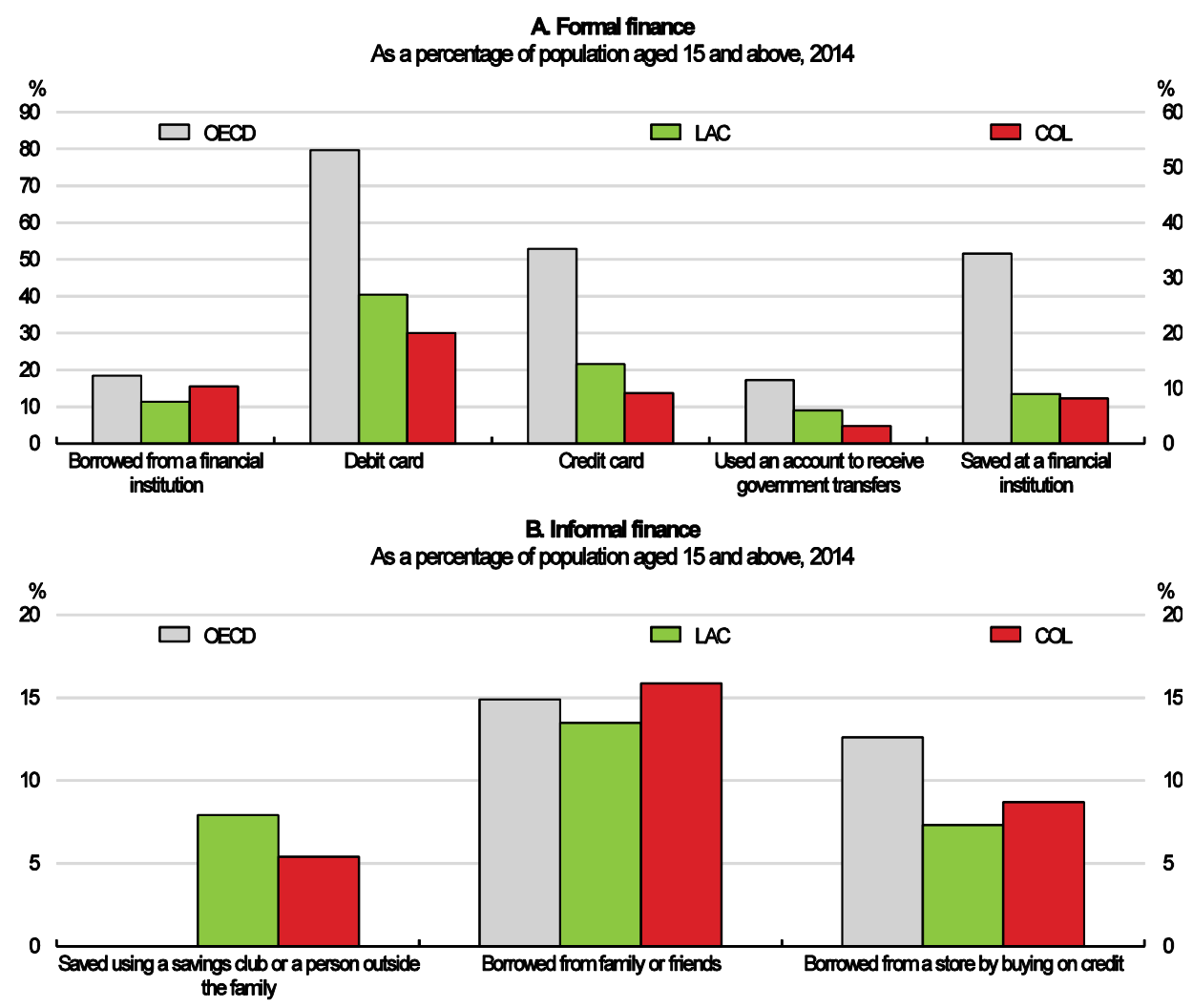

Note: OECD aggregate excludes Hungary, Iceland, Latvia, Mexico and Turkey. LAC refers to 23 countries in Latin America and the Caribbean (Argentina, Belize, Bolivia, Brazil, Chile, Colombia, Costa Rica, Dominican Republic, Ecuador, El Salvador, Guatemala, Haiti, Honduras, Jamaica, Mexico, Nicaragua, Panama, Paraguay, Peru, Puerto Rico, Trinidad and Tobago, Uruguay and Venezuela).

Source: Global Findex (Global Financial Inclusion Database).

Financial inclusion can be hindered by both supply-side barriers such as regulatory constraints, geographical or infrastructure barriers, and demand-side barriers such as low levels of financial literacy and linguistic barriers and reduced social and technological inclusion (Atkinson and Messy, 2013). The most affected people are often the young, the poorest socio-economic groups, those living in rural areas and the self-employed. 
An important way to address demand-side barriers is to promote financial education as a way of increasing financial literacy (Hinz, 2014, Atkinson and Messy, 2013). Financial literacy can be defined as a combination of awareness, knowledge, skill, and behaviour necessary to make sound financial decisions and ultimately achieve individual financial wellbeing (Atkinson and Messy, 2013). This can take many forms such as awareness campaigns, collective or individual training (Deb and Kubzansky, 2012). But many studies have found that these need to be well designed and carefully targeted to the relevant audience, as evidence indicates that not all financial education initiatives translate into a change in behaviour (OECD, 2005, OECD, 2015e, Cole and Fernando 2008, Deb and Kubzansky, 2012). Many countries aim at improving financial inclusion whilst recognising the importance of strengthening financial literacy skills (Box 1).

Financial education needs to be complemented by consumer protection regulations (Atkinson and Messy, 2013 and Hinz, 2014). The G20 highlights that consumer protection is the most relevant issue moving forward in financial inclusion. The leaders stipulate that integration of financial consumer protection policies into regulatory and supervisory frameworks contributes to strengthening financial stability (G20-OECD taskforce, 2013).

Financial inclusion has been an important priority for the Colombian government for a number of years. The National Financial Inclusion Strategy's goal is to promote access and use of financial services, in particular among informal workers. Policies have mainly aimed at providing microcredit to the poor, spreading formal banking system usage, enhancing the use of electronic payments and making financial services more affordable. The Government has subsidized the opening of bank accounts for most Familias en Accion transfer recipients and lowered the financial transaction tax on accounts with a low balance (Karpowicz, 2014). Making the transaction tax permanent, as suggested by the tax reform, may thus hamper financial inclusion. A 2014 law also created a simplified license for becoming a financial institution for transaction and payment purposes only, aimed at increasing the number of players in the financial sector. The government is promoting the use of alternative guarantees (collateral) and creating a registry of electronic invoices to increase access to financial services and facilitate credit to SMEs. In 2015 the financial inclusion commission was created to ease inter-institutional coordination in the development and implementation of financial inclusion initiatives. The Financial Superintendency (SFC) and Banca de las Oportunidades developed several financial inclusion indicators considering institutions supervised by the SFC, by Superintendencia de la Economía Solidaria and microcredit NGOs. According to the last report, $77.3 \%$ of Colombian adults had at least one financial product in June 2016. More should be done to promote financial education especially to the most vulnerable people such as the young, women, rural people and low socio-economic groups. 


\section{Box 1. Financial inclusion: experience in selected countries}

Financial inclusion is an important topic for inclusive growth in many countries (Atkinson, A. and F. Messy (2013)). A 2010 survey of financial regulators from 142 economies showed that $88 \%$ had some aspect of financial inclusion, financial education or financial consumer protection in their mandate (CGAP, 2010). The policy aims of financial education for financial inclusion are typically to strengthen an emergent financial service sector, or to provide consumers with the protection and skills they need to operate within the existing financial market in a way that promotes their own financial well-being and opportunities. The experience of Brazil, India, Portugal and Fiji are presented in this box.

\section{Brazil}

Financial inclusion has been a goal of the Central Bank of Brazil since the 1990s and was formally made a strategic objective of the Bank in 2010. In 2007, the Brazilian Committee for Regulation and Inspection of Financial, Capital, Insurance, Pension, and Capitalization Markets (Coremec) convened a working group to develop a national strategy for financial education. However, in its first report on financial inclusion in 2010 the central bank noted that the following challenges remained: (i) improvement of data on financial inclusion; (ii) wide-scale dissemination of credit services (especially microfinance) and savings; (iii) tailoring supervision mechanisms; (iv) strengthening the institutional structure of financial education and of protection of the users' rights (Banco Central do Brasil, 2010).

The Brazilian government has subsequently created the National Committee for Financial Education (CONEF) to coordinate the actions of regulators, the Ministry of Education and other government bodies (Tombini, Presentation for G20 Ministers' Meeting, 2012).

\section{India}

India aims at achieving financial inclusion on a massive scale. Indians face many barriers to financial inclusion, including a lack of branches in remote or poorer areas, the lack of formal identification documents, very low incomes, a lack of confidence in financial service providers and low levels of literacy, numeracy and financial literacy. On top of this, banks face a high cost to reaching out excluded populations and limited profit opportunities in the short term, as many of the potential clients have limited money to pay into financial institutions.

The Indian Financial Inclusion Plan is led by the government and the Reserve Bank of India (RBI) but it also includes regulatory bodies, banking associations, schools, NGOs and civil society. The RBI issued a directive requiring banks to draw up plans to provide bank services to rural areas with a population of at least 2,000. A banking service may be provided through either a branch or a 'business correspondent' i.e. an individual bank agent providing banking services door-to-door in unbanked areas through various devices such as mobile phones and micro ATMs. At least 4 products must be provided by the banking services in order to meet the conditions set by the RBI.

Various other changes have been necessary to action the Indian Financial Inclusion Plan. Improved, compatible technology was necessary to connect remote branches to main offices and to process transactions rapidly. Simplified authorization procedures were put in place to allow branches to open, and KYC requirements were relaxed on small accounts, to include simple introduction by someone who could prove their identity. Furthermore, widespread roll-out of unique identity numbers using biometric data has offered a unique opportunity for financial service providers to accurately identify their clients without the need for further documentation, and increase account security. Financial literacy initiatives have also been seen as key to addressing lack of confidence and knowledge about financial products and their uses; these have been delivered through a wide variety of channels, including schools, road shows, pamphlets and films.

\section{Portugal}

Portugal's goal is to provide basic banking services at low cost. In Portugal, household customers have access to a range of banking services deemed essential at a relatively low cost. The condition to access this regime is that consumers hold a single current account. The so-called basic banking services include the opening of a current account, the provision of a debit card and direct debits, and the access to the operation of the basic banking account through ATMs, home-banking service and credit institution's branches. These banking services are made available by credit institutions that voluntarily decide to provide them. Although it works on a voluntary basis, the credit institutions that decide to join this regime must comply with the rules.

Credit institutions cannot charge fees for basic banking services that annually exceed $1 \%$ of the monthly minimum wage. Consumers may acquire other banking products or services not included in the basic banking services package, such as term deposits, transfers or credit products, but for these products they are subject to the fees in force in the credit institution. 
Credit institutions must inform the public that they provide basic banking services through the disclosure of a notice at their branches and websites. In order to reinforce the dissemination of the basic banking services and promote financial inclusion, the information on these services is widely publicised on the National Plan for Financial Education website and the Bank Customer website. Also, financial education lectures on basic banking services and household budget management are organized for trainers working in institutions that deal with vulnerable groups of the population.

Fiji

A financial inclusion project in Fiji identified ways in which financial education could be better utilised to support the uptake of a new financial product provided as a means of receiving welfare payments (Leonard, 2011). The research showed that the first step for financial education in support of financial inclusion should be to "educate consumers on the usage of bank accounts and new technology".

The research indicated that financial education should not necessarily be targeted exclusively on the intended recipient of the product, but also on their households. This was felt to be particularly important where therecipient was elderly or disabled.

Source: Atkinson, A. and F. Messy (2013). 


\section{Policy recommendations to make growth more inclusive}

\section{Key recommendations}

- $\quad$ Further reduce taxes and fees on wages (non-wage labour costs).

- Simplify procedures for company registration and the affiliation of workers to social security.

- Establish social dialogue to discuss differentiating the minimum wage by age and regions.

- Ensure the provision of affordable, good-quality child care and affordable long-term care for elderly relatives or those with disabilities.

- $\quad$ Expand access to and make greater use of active labour-market programmes.

- Provide more public support to increase enrolment rates of disadvantaged children in less developed regions.

- Expand early childhood education.

\section{Other recommendations}

\section{Gender gap}

- $\quad$ Raise awareness among young men and women, parents, teachers and employers with campaigns about gender-stereotypical attitudes towards academic performance and the likely consequences of overall educational choices for employment and entrepreneurship opportunities, career progression and earnings

\section{Labour market}

- Increase income support to the unemployed and provide sufficient funding for employment service providers

- Restrict options to withdraw funds for reasons other than unemployment (like house purchase/renovation or education) in the system of individual unemployment savings accounts

\section{Education}

- $\quad$ Provide educational home visits and group meetings, delivering books and resources and giving Early Childhood Education and Care staff practical tools and materials to help them work effectively with families.

- Continue improving the initial education and professional development of the Early Childhood Education and Care workforce by introducing tailored, practical pedagogical professional training, ensuring at least a postsecondary level qualification at the same level as primary school teachers and actively recruiting and retraining excess staff from the primary sector

- $\quad$ Refocuse upper-secondary education teaching and learning on core skills and real-life applications to help students achieve basic skills; improve the relevance of VET options to the labour market by engaging employers in the design of programs, curricula, certification, and quality assurance; and improve the second chance opportunities available to students who have dropped out.

- Enhance public funding to low-income students, either through loans or scholarships. The ICETEX loan conditions could be more flexible for students from very low-income families or rural areas and more strict for those with less financial need.

Pension

- Thoroughly reform the pension system to reduce old-age poverty and inequality.

- Expand eligibility of the Beneficios Económicos Periódicos programme.

- Increase coverage and benefit levels of the minimum public income-support programme (Colombia Mayor).

- Equalise the retirement age between men and women. In the medium term, increase the retirement age and link it to life expectancy evolution.

Health

- $\quad$ Explore ways how the wider primary care workforce can contribute to the country's health care challenges. Remove legal obstacles to extending nurses' and other professionals' roles in health care. 
- In rural and remote areas, encourage outreach specialists to act as mentors to local health care workers, building knowledge and confidence, encouraging continuity of care and, most importantly, forging a sustained service network between rural and urban health care providers.

\section{Financial inclusion}

- Enhance financial education and target it to the most vulnerable people such as the young, women, rural people and low socio-economic groups. 


\section{REFERENCES}

Allen, F. E. Carletti, R. Cull, J. Qian, L. Senbet, and P. Valenzuela (2013)," Resolving the African Financial Development Gap: Cross-Country Comparisons and a Within-Country Study of Kenya", World Bank Policy Working Paper No. 6592. Washington, DC.

Álvarez Marinelli, H., A. Nury Martínez, M. Pinzón Caicedo and L.J. Piñeros (forthcoming)," Nota de Política: Oportunidades y Desafíos en el Sector Educativo Colombiano," Inter-American Development Bank, Bogotá.

Atkinson, A. and F. Messy (2013), "Promoting Financial Inclusion through Financial Education: OECD/INFE Evidence, Policies and Practice", OECD Working Papers on Finance, Insurance and Private Pensions, No. 34, OECD Publishing.

Azevedo V. and Bouillon C. (2010), "Intergenerational Social Mobility in Latin America: a Review of Existing Evidence”, Revista de Análisis Económico, Vol. 25, No2, pp 7-42.

Baker, M., J. Gruber, and K. Milligan (2005), "Universal childcare, maternal labour supply, and family well-being," NBER Working Paper Number 11832.

Banco Central do Brasil (2010), Report on Financial Inclusion, Number 1,2010 Brasilia, http://www.bcb.gov.br/Nor/relincfin/report_on_financial_inclusion_n1_2010.pdf.

Barrera, M. (2014)," La Educación Básica y Media en Colombia: Retos en Equidad y Calidad", Fedesarrollo: Centro de Investigación Económica y Social, Bogotá, Colombia.

Bauernschuster, S. and M. Schlotter (2015), "Public childcare and mothers' labour supply - evidence from two quasi-experiments." Journal of Public Economics. 123:1-16.

Bernal, R. (2014), "Diagnóstico y recomendaciones para la atención de calidad a la primera infancia en Colombia", Cuadernos Fedesarrollo, No. 51, Fedesarrollo, Bogotá, Colombia, www.fedesarrollo.org.co/wp-content/uploads/2014/04/debate_pres_2014_cuad51.pdf.

Bonet, J. and J. Urrego (2014), “El Sistema General de Regalías: ¿mejoró, empeoró o quedó igual?" Documentos de trabajo de economía regional, No. 198, Banco de la Republica, Centro de Estudios Económicos Regionales, Cartagena.

Burgess, R. and R. Pande. 2005," Do Rural Banks Matter? ,Evidence from the Indian Social Banking Experiment", American Economic Review,95(3): pp. 780-795.

Causa, O. and Å. Johansson (2009), "Intergenerational Social Mobility", OECD Economics Department Working Papers, No. 707, OECD Publishing.

CGAP/World Bank (2010), Financial Access 2010, The State of Financial Inclusion through the Crisis, http://www.microrate.com/media/docs/general/FA_2010_Financial_Access_2010_Rev.pdf.

CIPI (2013)," De Cero a Siempre: Informe de Seguimiento y Evaluación a la Estrategia de Atención Integral a la Primera Infancia", Comisión Intersectoral de Primera Infancia (Intersectoral 
Commission for the Comprehensive Care of Early Childhood), Bogotá, www.deceroasiempre. gov.co/QuienesSomos/Paginas/Documentos.aspx.

Cole S., Fernando N. (2008), "Assessing the Importance of Financial Literacy", Asian Development Bank, 2008.

Corak M. (2013), "Income Inequality, Equality of Opportunity, and Intergenerational Mobility", Journal of Economic Perspectives - Volume 27, Number 3 -summer 2013-Pages 79-102.

DANE - National Statistics Authority (2011), "Encuesta Nacional de Calidad de Vida", www.dane.gov.co/index.php/esp/estadisticas-sociales/calidad-de-vida-ecv/87- sociales/calidad-devida/3281-encuesta-de-calidad-de-vida-2011.

Daude C. and V. Robano (2015), "On intergenerational (im)mobility in Latin America”, Lat Am Econ Rev (2015), 24:9.

Deb, A., and M. Kubzansky (2012)," Bridging the Gap: The Business Case for Financial Capability", A report commissioned and funded by the Citi Foundation, Cambridge, Mass: Monitor, March.

De la Maisonneuve, C. (2015), "Reforming the pension system to increase coverage and equity in Colombia”, OECD Economics Department Working Papers, No. 1235, OECD Publishing, Paris.

Evidencia reciente," Documento de trabajo sobre economía regional", No.177, Banco de la República, Centro de Estudios Económicos Regionales, Cartagena.

Ferrant, G., L.M. Pesando and K. Nowacka (2014), "Unpaid Care Work: The Missing Link in Analysis of Gender Gaps in Labour Outcomes”, Issues Paper, OECD Development Centre.

Ferreira F.H.G and M. Melendez (2012), "Desigualdad de Resultados y Oportunidades en Colombia: 19972010", Documentos CEDE 2012-40, Universidad de los Andes-Facultad de Economía-CEDE.

Ferreira F.H.G, Lakner C., M.A Lugo. And B. Ozler (2014), "Inequality of Opportunity and economic growth: A cross-country analysis", ECINEQ Working Paper No 335.

Frey, V., A. Jaoui, and T. Manfredi (2017), "Gender inequality in Colombia vis-à-vis OECD countries", Economics Department Technical Background Paper.

Galvis, L.A. and A. Meisel (2012), "Convergencia y trampas espaciales de pobreza en Colombia".

Gamboa L.F. and E. Londono (2015), “Assessing Educational Unfair Inequalities at a Regional Level in Colombia”, Lecturas de Economía, 83 (julio-diciembre 2015), pp. 97-133

Gamboa L.F, and F.D. Waltenberg, "Inequality of opportunity for educational achievement in Latin America: Evidence from PISA 2006-2009 ", Economics of Education Review ,31 (2012) 694708.

García S., C.Rodríguez, F. Sánchez and J.G.Bedoya (2015), "La lotería de la cuna: La movilidad social a través de la educación en los municipios de Colombia”, Documentos CEDE, No 31.

Garcia Villegas, M., J.R. Espinosa Restrepo, F. Jimenez Angel and J.D. Parra Heredia (2013)," Separados y Desiguales: Educación y Clases Sociales en Colombia", Centro de Estudios de Derecho, Justicia y Sociedad, Dejusticia, Bogotá. 
Garibaldi, P. and G. Violante, (2005), "The Employment Effects of Severance Payments with Wage Rigidities", The Economic Journal, Vol. 115.

Gonzales C.et al. (2015), "Catalyst for Change: Empowering Women and Tackling Income Inequality", IMF Staff discussion note.

Gutierrez, L., C. Pombo and R. Taboada (2005), “Ownership and Control in Colombian Corporations",Mimeo.

Heras Recuero L. and E.Olaberria (2017), "Public Spending in Education and Students' Performance in Colombia", OECD Economics Department Working Papers, forthcoming.

Hinz M. (2014), “The fundamentals of financial inclusion: an overview”, BBVA research, Mimeo.

Hoeller, P., I. Joumard, M. Pisu and D. Bloch (2012), "Less Income Inequality and More Growth - Are They Compatible? Part 1. Mapping Income Inequality Across the OECD”, OECD Economics Department Working Paper, No. 924, OECD publishing, Paris.

ICRC (2011), "Informe de actividades Colombia 2011 - situación humanitaria”, International Committee of the Red Cross ,www.icrc.org/spa/resources/documents/feature/2012/colombia-report-2012-0418.htm.

IMF (2016), "Financial Access Survey”, International Monetary Fund.

Joumard, I. and J. Londoño Vélez (2013), "Income Inequality and Poverty in Colombia - Part 1. The Role of the Labour Market", OECD Economics Department Working Papers, No. 1036, OECD publishing.

Karpowicz, I. (2014), "Financial Inclusion, Growth and Inequality: A Model Application to Colombia", IMF Working Paper No 166.

Leonard, M.(2011), G2P: Expanding Financial Inclusion in the Pacific Fiji's Transfer of Social Welfare Recipients to a Savings-Linked Electronic Payment System, http://www.uncdf.org/sites/default/files/Download/PFIP_G2P.pdf.

Lindbeck, A. and D.J. Snower, (1988), "The Insider-Outsider Theory of Employment and Unemployment”, MIT Press, Cambridge, MA.

López-Calva, L.F. and N. Lustig (2010)," Declining Inequality in Latin America: A Decade of Progress?" Brookings Institution Press.

MEN (2013a), "Hacia un pensamiento estratégico para el fortalecimiento de la Educación media: síntesis de estudios", unpublished document, Ministerio de Educación Nacional (Ministry of National Education), Bogotá.

Miranda, V. (2011), "Cooking, caring and volunteering: Unpaid work around the world", OECD Social, Employment and Migration Working Papers, No. 116, OECD Publishing, Paris.

Moya A. and M.Carter (2014), "Violence and the formation of hopelessness and pessimistic prospects of upward mobility in Colombia", NBER Working Paper, No 20463.

Núñez, J. (2009), "Incidencia del Gasto Público Social en la Distribución del Ingreso, la Pobreza y la Indigencia”, Departamento Nacional de Planeación, Archivos de Macroeconomía, No. 359. 
OECD (2005), "Improving Financial Literacy, Analysis of Issues and Policies”, OECD Publishing, Paris.

OECD (2011), Divided We Stand, Why Inequality Keeps Rising, OECD publishing.

OECD (2012a), "Starting Strong III: A Quality Toolbox for Early Childhood Education and Care", OECD Publishing, Paris.

OECD (2012b), Closing the Gender Gap: Act Now, OECD Publishing.

OECD (2013a), PISA 2012 Results: What Makes Schools Successful? (Volume IV): Resources, Policies and Practice, PISA, OECD Publishing, Paris.

OECD (2013b), PISA 2012 Results: Excellence through Equity (Volume II): Giving Every Student the Chance to Succeed, PISA, OECD Publishing, Paris.

OECD (2014), OECD Territorial Reviews: Colombia 2014, OECD Publishing.

OECD (2015a), OECD Review of Agricultural Policies: Colombia 2015, OECD Publishing.

OECD (2015b), Education at a Glance, OECD Publishing, Paris.

OECD (2015c), OECD Economic Surveys: Colombia 2015, OECD Publishing.

OECD (2015d), OECD Reviews of Health Systems: Colombia 2016, OECD Publishing, Paris.

OECD (2015e), "National Strategies for Financial Education", OECD/INFE Policy Handbook.

OECD (2016a), "Gender Equality in the Pacific Alliance: Promoting Women's Economic Empowerment", OECD Publishing, Paris.

OECD (2016b), OECD Employment Outlook 2016, OECD Publishing, Paris.

OECD (2016c), OECD Reviews of Labour Market and Social Policies: Colombia 2016, OECD Publishing.

OECD (2016d), OECD Health Statistics 2016.

OECD (2016e), Education in Colombia, Reviews of National Policies for Education.

OECD (2016e), PISA 2015 Results (Volume I): Excellence and Equity in Education, PISA, OECD Publishing, Paris.

Olaberría O. (2017)," Reigniting growth through productivity, enhancing reforms in Colombia", OECD Economics Department Working Papers, forthcoming.

Park C.Y. and R.V.Mercado (2015), "Financial inclusion, poverty and income inequality in developing Asia", Asian Development Bank Economics Working Paper No 426.

Rodríguez C. \& F. Sánchez (2012), “Armed Conflict Exposure, Human Capital Investments, and Child Labor: Evidence From Colombia”, Defence and Peace Economics, 23:2, 161-184.

Thévenon, O. (2015), "Do 'institutional complementarities' foster female labour force participation?" Journal of Institutional Economics 12:2, 471-497.

UNESCO -UIS (2015), "Browse by theme: Education”, Data Centre, UNESCO Institute for Statistics. 
Vegas, E. and L. Santibáñez (2010), "The Promise of Early Childhood Development in Latin America and the Caribbean", the World Bank.

World Bank (2010), "Informality in Colombia: Implications for Worker Welfare and Firm Productivity", Report No. 42698-CO, Washington. 